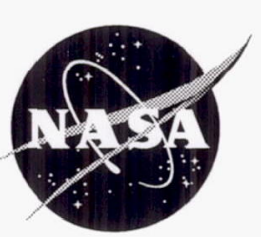

\title{
Lessons Learned From the Construction of Upgrades to the NASA Glenn Icing Research Tunnel and Re-Activation Testing
}

David W. Sheldon, Charles R. Andracchio, and Thomas M. Krivanek

Glenn Research Center, Cleveland, Ohio

David A. Spera and Todd A. Austinson

Dynacs Engineering Company, Inc., Brook Park, Ohio 
Since its founding, NASA has been dedicated to the advancement of aeronautics and space science. The NASA Scientific and Technical Information (STI) Program Office plays a key part in helping NASA maintain this important role.

The NASA STI Program Office is operated by Langley Research Center, the Lead Center for NASA's scientific and technical information. The NASA STI Program Office provides access to the NASA STI Database, the largest collection of aeronautical and space science STI in the world. The Program Office is also NASA's institutional mechanism for disseminating the results of its research and development activities. These results are published by NASA in the NASA STI Report Series, which includes the following report types:

- TECHNICAL PUBLICATION. Reports of completed research or a major significant phase of research that present the results of NASA programs and include extensive data or theoretical analysis. Includes compilations of significant scientific and technical data and information deemed to be of continuing reference value. NASA's counterpart of peerreviewed formal professional papers but has less stringent limitations on manuscript length and extent of graphic presentations.

- TECHNICAL MEMORANDUM. Scientific and technical findings that are preliminary or of specialized interest, e.g., quick release reports, working papers, and bibliographies that contain minimal annotation. Does not contain extensive analysis.

- CONTRACTOR REPORT. Scientific and technical findings by NASA-sponsored contractors and grantees.
- CONFERENCE PUBLICATION. Collected papers from scientific and technical conferences, symposia, seminars, or other meetings sponsored or cosponsored by NASA.

- SPECIAL PUBLICATION. Scientific, technical, or historical information from NASA programs, projects, and missions, often concerned with subjects having substantial public interest.

- TECHNICAL TRANSLATION. Englishlanguage translations of foreign scientific and technical material pertinent to NASA's mission.

Specialized services that complement the STI Program Office's diverse offerings include creating custom thesauri, building customized data bases, organizing and publishing research results ... even providing videos.

For more information about the NASA STI Program Office, see the following:

- Access the NASA STI Program Home Page at http://www.sti.nasa.gov

- E-mail your question via the Internet to help@sti.nasa.gov

- Fax your question to the NASA Access Help Desk at 301-621-0134

- Telephone the NASA Access Help Desk at 301-621-0390

- Write to: NASA Access Help Desk NASA Center for AeroSpace Information 7121 Standard Drive Hanover, MD 21076 


\section{Lessons Learned From the Construction of Upgrades to the NASA Glenn Icing Research Tunnel and Re-Activation Testing}

David W. Sheldon, Charles R. Andracchio, and Thomas M. Krivanek Glenn Research Center, Cleveland, Ohio

David A. Spera and Todd A. Austinson

Dynacs Engineering Company, Inc., Brook Park, Ohio

Prepared for the 39th Aerospace Sciences Meeting and Exhibit sponsored by the American Institute of Aeronautics and Astronautics Reno, Nevada, January 8-11, 2001

National Aeronautics and Space Administration

Glenn Research Center 
Available from

NASA Center for Aerospace Information 7121 Standard Drive

Hanover, MD 21076

Price Code: A03
National Technical Information Service 5285 Port Royal Road Springfield, VA 22100 Price Code: A03 


\title{
LESSONS LEARNED FROM THE CONSTRUCTION OF UPGRADES TO THE NASA GLENN ICING RESEARCH TUNNEL AND RE-ACTIVATION TESTING
}

\author{
David W. Sheldon, Charles R. Andracchio, and Thomas M. Krivanek \\ National Aeronautics and Space Administration \\ Glenn Research Center \\ Cleveland, Ohio 44135
}

\author{
David A. Spera and Todd A. Austinson \\ Dynacs Engineering Company, Inc. \\ Brook Park, Ohio 44142
}

\begin{abstract}
$\underline{\text { Abstract }}$
Major upgrades were made in 1999 to the 6-ft by 9-ft $(1.8 \mathrm{~m}$ by $2.7 \mathrm{~m}$ ) Icing Research Tunnel (IRT) at the NASA Glenn Research Center. These included replacement of the electronic controls for the variablespeed drive motor, replacement of the heat exchanger, complete replacement and enlargement of the leg of the tunnel containing the new heat-exchanger, the addition of flow-expanding and flow-contracting turning vanes upstream and downstream of the heat exchanger, respectively, and the addition of fan outlet guide vanes (OGV's).
\end{abstract}

This paper presents an overview of the construction and reactivation testing phases of the project. Important lessons learned during the technical and contract management work are documented.

\section{Nomenclature}

A to $\mathrm{D}$ 1st to 4 th tunnel corners

HX heat exchanger

IRT Icing Research Tunnel (6' x 9')

OGV fan outlet guide vane

SMIRT $1 / 10$ th Scale Model Icing Research Tunnel

\section{Introduction}

Research in aircraft icing and component icing qualification tests have been conducted in the Icing Research Tunnel (IRT) at the NASA Glenn Research Center (GRC, formerly the Lewis Research Center) for over fifty-five years. ${ }^{1}$ A wide variety of civilian and military aircraft components and ice-protection systems have been tested in the IRT under icing conditions. Test articles are usually full-scale or nearly full-scale in size, because scaling laws for icing are subjects of current research.
In addition to NASA, organizations sponsoring tests in the IRT include the FAA, the Department of Defense, and both large and small manufacturers of airframes and aircraft engines. Private organizations compensate NASA for the use of the IRT in accordance with formal agreements authorized by the Space Act of 1958. In recent years the IRT has been one of NASA's busiest wind tunnels

\section{Previous Upgrades and Long-Range Plans}

Although the basic structure of the IRT dates back to 1944, many components of the facility have been upgraded since that time. In addition, instrumentation, controls, and data acquisition systems have been regularly upgraded to include current technology. Major upgrades to the IRT are listed in Table 1. The fan drive motor was replaced in 1986, doubling the available power to 5,000 horsepower. Tunnel controls were upgraded from analog to digital. In 1992 and 1993 the insulation on a large portion of the tunnel was upgraded and an external force balance was installed. In 1993 new fan blades were installed with pitch angles modified to use all the available power in the drive motor. This resulted in an increase in maximum tunnel airspeed from 305 to 420 miles per hour.

In 1994 an IRT Long-Range Improvement Plan was developed, in which the following four goals were established: (1) Increasing the size of the uniform icing cloud in the test section, (2) improving and increasing the capability of the spray system, (3) improving the tunnel's aerodynamic flow quality under dry operating conditions, and (4) increasing the maximum airspeed in the tunnel. This long-range planning resulted in the successful advocacy for a new spraybar system (1996/97) and a replacement heat exchanger (1999), as noted in Table 1. It is this latest upgrade program that is the subject of this paper. 
The first three of the goals of the long-range plan have now been met through the successful completion of these latest two upgrade programs. It is now clear that the fourth goal, that of increasing the tunnel's maximum airspeed above the $420 \mathrm{mph}$ achieved in 1994, is not achievable with the current drive motor. Also, the noise levels in the control room during operations at airspeeds above $400 \mathrm{mph}$ were found to be too high for sustained testing. After the new heat exchanger was installed in 1999 there was a further reduction in maximum airspeed to about $390 \mathrm{mph}$ under dry operating conditions. However, during icing sprays the tunnel airspeed does not decrease significantly with the buildup of frost on the new heat exchanger. Therefore, tunnel operations during icing tests continue to meet most customer test matrix requirements.

\section{Purpose and Scope}

Most of the work conducted under this upgrade program proceeded as designed and planned. However, during the construction and reactivation phases there were lessons learned that may be useful in future projects. The purpose of this paper is to present an overview of the construction and reactivation testing phases of the 1999 IRT upgrade program and to document important lessons learned during both the technical and contract management efforts. The planning and design aspects of this upgrade program are described in reference 2 and will not be covered here.

\section{IRT Loop Before Modification}

A plan view of the original loop configuration of the IRT is shown schematically in Figure 1. In this plan view, air circulates in a counter-clockwise direction around the tunnel loop, which is rectangular in crosssection except at the drive fan where it is circular. Starting at the Stilling Chamber in the lower left corner, low-velocity chilled air passes through the spray bar section where heated air and water droplets are sprayed into the stream from an array of nozzles.

The airflow carrying a cloud of super-cooled water droplets is then accelerated in the Convergence Section and enters the Test Section, at airspeeds up to approximately $400 \mathrm{mph}$. In the Test Section, water droplets freeze on contact with a test article that is usually mounted on the turntable in the tunnel floor and rotated to the desired angle of attack. The airflow then exits the Test Section and begins its deceleration in the Diffuser, which extends through Corners A and B. Each of these corners contains a cascade of vanes that turn the flow 90 degrees with minimal losses and turbulence.

Downstream of Corner B the duct shape transitions from rectangular to circular, and the flow enters the Fan Section through a radial array of fan inlet guide vanes
(IGVs). Here the airflow is swirled clockwise (looking downstream), which partially counters the swirl imparted later by the counter-clockwise rotation of the fan blades and reduces flow angularity downstream. The total pressure in the air stream is raised by the fan, in the amount required to offset pressure losses that occur throughout the rest of the tunnel loop. Air temperature is also increased as a result of the heat of compression. This is the main source of heat that must be removed from the tunnel by the heat exchanger further downstream.

The outflow of the fan passes through a transition duct, which changes in cross-sectional shape from circular to rectangular, and then through the Vent Tower Section. The movable sidewalls of the vent tower are normally closed, but after icing tests they can be moved inward to allow outside air to mix with the flow and help dry out the tunnel.

From the vent tower the flow passes through the turning vanes in Corner $\mathrm{C}$ and then through the heat exchanger, where its temperature is lowered. As illustrated in Figures 2(a) and (b), the fin-tube panels of the original heat exchanger are arranged in the shape of a "W" laid on its side. This increases the flow areas of the individual panels and thereby decreases airspeeds over the coolant tubes to an acceptable level. The flow then passes through the turning vanes in Corner $\mathrm{D}$ and back to the Stilling Chamber.

\section{Deficiencies to be Corrected by Upgrades}

In recent years, deficiencies in the operation and maintenance of the IRT clearly indicated that certain components in the supply legs of the tunnel - from the fan to the Stilling Chamber - needed to be replaced and improved. The current upgrade program was designed to correct the following deficiencies:

\section{Obsolete Electronic Controls for the Fan Motor}

The 5,000-hp synchronous motor driving the IRT fan was installed in 1986 with a "Varichron" AC-DC-AC electrical system for variable-speed operation. The microcomputer controlling all electrical system operations, which was designed according to the state of the technology in the early 1980s, had become obsolete. The company that owned the Varichron design was phasing out technical support for this control system. Because of their age, the electronic components in the microcomputer were failing in increasing numbers with each passing year. Troubleshooting and diagnostics were becoming more and more difficult. Spare and replacement parts were very hard to locate and, when found, were extremely expensive. 


\section{Deterioration of the Heat Exchanger}

The Carrier Corporation installed the large copper tubecopper fin heat exchanger, with a nominal refrigeration capability of 2100 tons, in the IRT in 1943. After more than 50 years of service, the network of copper tubes was deteriorating to the point where the repair or closing-off of leaking tubes was responsible for about 100 hours of tunnel downtime each year. Leaks were occurring at silver-soldered joints at the end turns of the tubes, which were caused by the incompatibility of the R-134a coolant and silver solder.

\section{Corrosion of the C-D Leg Floor and Ceiling}

Over the years, residual water from icing tests had badly corroded the steel floor plates in the C-D leg. Rainwater had also seeped under the roofing material, saturating of the roof insulation and corroding the ceiling plates. Condensation on the outer surfaces of the steel plates also added to the corrosion. Local repairs were made, but it was clear that the steel structure in the C-D leg could not be easily modified to support a new heat exchanger. In addition, the existing heat exchanger and the surrounding steel structure were so closely connected that it was impractical to replace the heat exchanger without replacing a large portion of the structure as well.

Flow Distortions from the W-Shaped Heat Exchanger and Motor Stand Leg Fairings

The airflow in the supply legs, from the vent tower section downstream of the fan through the refrigeration heat exchanger and into the stilling chamber has been shown to be unevenly distributed across duct flow areas. ${ }^{3,4}$ The two main causes of these flow distortions were the "W" shape of the heat exchanger and the presence of two large fairings around the legs of the fan motor support stand below the fan motor nacelle. These leg fairings are shown in Figure 3. The non-uniform distribution of airspeed across the heat exchanger produced non-uniform cooling rates, and this required a complicated balancing of the coolant flow through the various $\mathrm{HX}$ panels in order to achieve a uniform air temperature in the Test Section.

\section{IRT Upgrade Program}

\section{Objectives}

The objectives of the 1999 IRT upgrade program, in priority order, are as follows:

1. Modernize the electronic controls of the fan motor and eliminate the excessive maintenance time and costs required now to keep the existing, obsolete Varichron microprocessor operational.

2. Replace the aging heat exchanger and eliminate the downtime required now for repairing leaks.
3. Replace the corroded and leaking steel tunnel structure in the C-D leg, particularly in the floor and ceiling plates.

4. Improve the quality of the airflow into the spraybars, removing distortions and turbulence caused by the "W" shape of the original heat exchanger.

5. Improve the uniformity of temperature in the airflow into the spraybars and the Test Section.

6. Improve the insulation on the walls and roof of the C-D leg and add insulation to the floor, reducing the thermal load on the heat exchanger.

The goal of the program is to obtain these objectives without reducing the overall performance of the IRT in its icing environment. The various phases of the current upgrade program are listed in Table 2, together with the performing organizations, dates, and (where applicable) costs for each

\section{Summary of Modifications to the IRT}

Figure 4 illustrates the IRT loop after the 1999 modifications were made in the air supply leg, from the drive fan to the Stilling Chamber. Starting at the drive fan, the microprocessor in the original Varichron electrical supply to the variable-speed drive motor was replaced with modern electronic components. Figure 5 is a schematic diagram of the motor electrical system. It was determined that the maintenance problems with the drive were centered in the obsolete microcomputer. The other hardware in the system worked well, without any of the deficiencies described earlier. Therefore, only the obsolete microcomputer was replaced.

Fan outlet guide vanes (OGV's) were installed radially around the fan motor housing, immediately downstream of the fan blades, to remove swirl from the outflow of the fan and thereby reduce airspeed variations downstream. Figure $\mathbf{6}$ shows the installation of these outlet guide vanes. The selected OGV design was that of a set of hollow, cambered and twisted airfoils placed radially outward from the fan motor housing at 24-deg intervals. ${ }^{6}$ These were fabricated from carbonreinforced fiberglass, with uniform chords of 71.7 in. $(1,821 \mathrm{~mm})$.

A design requirement for the new outlet guide vanes was a minimum natural frequency of $100 \mathrm{~Hz}$. This relatively high frequency, which is just above the maximum blade passing frequency, was specified in order to avoid any possible resonance between the OGV's and the fan blades. An initial OGV design met all strength requirements but failed to meet the frequency requirement, even when the airfoil walls were stiffened by two internal spars and the laminate was reinforced with carbon fibers. The entire airfoil was then thickened, particularly in the trailing edge 
region where panel vibration frequencies were below the requirement. The structural frequency requirement was met by this second design, but the resulting thick aerodynamic shape was not optimal.

The entire C-D leg of the tunnel, which extends from just downstream of the Vent Tower to just upstream of the Stilling Chamber, was demolished and replaced with a new C-D leg significantly different is size and construction. The demolition work included abatement of lead paint and removal of contaminated soil. The width of the leg was increased 69 percent, from 29.2 feet $(8.89 \mathrm{~m})$ to 49.2 feet $(15.0 \mathrm{~m})$, to accommodate a new flat heat exchanger. A basement was added that contains the main coolant supply and return pipes and instrumentation cables. The basement also allowed the application of spray-on insulation to the underside of the tunnel floor. Figures 7 and 8 show views of the demolition of the original C-D leg and the beginning of the construction of the new C-D leg.

New cascades of turning vanes were installed in Corners C and D, each consisting of 16 hollow fiberglass airfoils 26.2 feet $(7.98 \mathrm{~m})$ in span and oriented vertically. As shown in Figures 9, 10, and 11, these vanes were fabricated in three sections and tied together by horizontal fiberglass plates. The tie plates were anchored to the tunnel's inner wall to help carry the lateral airloads on the turning vanes. These customdesigned turning vanes expand the flow in Corner $\mathrm{C}$ and contract the flow in Corner $\mathrm{D}$, and their unique aerodynamic shapes make them relatively insensitive to incoming flow angles. ${ }^{5}$ The large size of the flow paths between vanes permits personnel access to either face of the $\mathrm{HX}$, for inspection and repair work.

The replacement heat exchanger, located in the new C-D leg, presents a flat surface to the airflow, in order to eliminate the flow distortions caused by the "W" shape of the original HX. The new HX consists of eight identical modules stacked in two sets of four, to form two separate units. Figures $\mathbf{1 2}$ to $\mathbf{1 5}$ show the installation of the new HX modules. Each module is divided into three zones in the flow direction, and each zone has its own supply and return headers for the coolant, R-134a. Coolant tubes run horizontally from a secondary supply header at the tunnel wall to midtunnel and then turn 180 degrees and back to a secondary return header. The units are offset from one another as shown in Figures 5 and 14, to permit inspection and maintenance of the U-fittings welded onto the ends of the coolant tubes at mid-tunnel.

Larger numbers of thermocouple probes were installed in Corners C and D, in order to measure the distribution of air temperature across the flows entering and leaving the HX and monitor the thermal performance of each of the eight HX modules. These probes are mounted on the leading edges of the fiberglass turning vanes, as shown in Figure 16. Sixteen probes were installed on the Corner $\mathrm{C}$ turning vanes, with two probes at the midelevation of each HX module. Twenty-four thermocouple probes were installed on the Corner D turning vanes, with three at the mid-elevation of each HX module. Each probe contains two Type T thermocouples for redundancy. One signal goes to the WDPF tunnel control system computer and the other goes to the Glenn ESCORT data acquisition system.

\section{Construction Phase}

A request for bids to replace the electronic controls for the fan motor was released in late 1998. The vast majority of responses were for complete new systems, not just an upgrade of the electronic controls. The reasoning behind these broader responses was that interfacing a modern controller with an older electrical system would require significant modifications to the code in the controller, as well as modifications to the controller hardware.

The cost of replacing all electrical and electronic equipment feeding the drive motor was approximately five times that of replacing only the electronic controls. Not surprisingly, a contract solely for replacement of the original microprocessor was awarded to the company owning the original Varichron design, Alstom Drives and Controls, Inc. (Pittsburgh, Pennsylvania), which had the intimate knowledge of both the old and new controls necessary to interface these two systems. Alstom personnel installed the new controls without requiring additional time or cost, which verified the cost-effectiveness of replacing only the obsolete microcomputer.

The prime contract for demolishing the existing C-D leg, building the modified leg on new foundations and a basement, installing the new $\mathrm{HX}$ with its piping system, and installing new corner turning vanes and fan outlet guide vanes was awarded to the East-West Construction Company (Cleveland, Ohio) in July 1997. Principal subcontractors were the FrigidCoil/Imeco Corporation, which fabricated the replacement heat exchanger and delivered it to the site, and Engineering Laboratory Design, Inc., which designed, fabricated, and installed the composite turning vanes in Corners $\mathrm{C}$ and $\mathrm{D}$ and the outlet guide vanes (OGV's) around the fan motor housing.

Preparation of shop drawings, ordering of materials and parts, and other work outside the tunnel (Phase 1) commenced in August 1997. Demolition and construction work (Phase 2) began on May 10, 1999. The tunnel was ready for re-activation tests on November 23, 1999, with completion of the contract work on April 28, 2000. The entire construction duration was 1,003 days. 


\section{$\underline{\text { Reactivation Phase }}$}

A comprehensive series of reactivation tests was begun in December 1999, near the end of the construction phase of the upgrade program. ${ }^{7}$ The most important of these reactivation tests are listed in Table 2, together with their objectives.

Reactivation of the IRT began with static and low-speed checkouts of the new electronic controls for the fan motor. Motor speed was then gradually increased to its maximum allowable level of $460 \mathrm{rpm}$ to verify safe and stable operation of the motor controls and the aerostructural integrity of components such as the fan blades, the new turning vanes, and the new OGV's. Strain gages on the fan blades and accelerometers on the turning vanes and OGV's were used to monitor stresses and vibrations, which were all below allowable limits.

Prior to the reactivation testing, accelerometers were mounted at selected locations on sample OGV's to measure any motions that might occur during fan operations. Preliminary static impact or "twang" tests were performed to determine the actual natural frequencies of the OGV's, as manufactured and asinstalled. Minimum natural frequencies were measured at $56 \mathrm{~Hz}$, well below the design prediction of $100 \mathrm{~Hz}$. This decrease in frequency was attributed to a clearance gap between the inner end of the OGV and its sliding socket support on the fan motor housing. The gap was filled at intervals with a rubber sealant, which permitted motions, that were not accounted for in the vibration analysis.

Accelerations were monitored closely during the fan startup, as fan speed was gradually increased to its maximum of $460 \mathrm{rpm}$. Extremely small motions were detected, which had no structural significance. Thus, it was concluded that the OGV's are free of resonant vibrations, even though their fundamental frequency is about one-half of the design requirement. These accelerometer tests verified that any air pressure variations from the passing fan blades are too small to excite vibrations in the OGV's. A second conclusion drawn is that the first OGV design, with its preferred thinner airfoil, would also have been structurally acceptable.

Preliminary flow-visualization studies were conducted using tufts attached to OGV surfaces. The results indicate that airflow over large portions of the thick OGV's may be separated, producing relatively high drag losses. More studies are planned to determine if the addition of small vortex generators would be beneficial in reattaching the flow in these areas of separation.

Figure 17 shows a comparison of the test airspeeds achievable before and after tunnel modifications, with an empty test section and dry, ambient air temperature conditions. It can be seen from this chart that the maximum airspeed attainable in the IRT has decreased from its historic high of $420 \mathrm{mph}$ (188 meter/s) measured during the 1994 qualification of new fan blades to approximately $390 \mathrm{mph}$ (174 meter/s) today. This decrease is attributed to an approximately 50 percent increase in the drag losses across the flat $\mathrm{HX}$ compared with the original W-shaped $\mathrm{HX}$, and to more drag loss than expected at the OGV's.

In Figure 18, pressure drops measured across the new $\mathrm{HX}$ are compared with design pressure drops. The range labeled "preliminary design" is a direct application of pressure drops measured across the original W-shaped heat exchanger, where heavy frost doubled the pressure drop. ${ }^{16}$ In the final design of the replacement $\mathrm{HX}$, however, frost was expected to cause only a small increase in the pressure drop. The two final design points at the bottom of the range show this, which represent operation at a test airspeed of $300 \mathrm{mph}$ (134 meter/s). Pressure losses across the new HX with or without frost were expected to be about the same as those with the original $\mathrm{HX}$ in a dry condition. Examination of the actual pressure drops measured across the new $\mathrm{HX}$ with and without frost shows that the minor effect of frost was correctly predicted. While the pressure losses without frost at the design point are about 70 percent higher than predicted, losses for the frosted condition are still lower than those for the original HX. Therefore, these additional drag losses at the $\mathrm{HX}$ are not expected to significantly affect tunnel operations during icing tests at moderate airspeeds and with test section blockage.

Next, the new HX was brought on-line to verify the function of valves and controls. The coolant flows to each of the eight HX modules and their 24 controllable zones were then balanced to minimize temperature variations downstream. During these tests it was determined that the 24 remotely controlled pressureregulating valves (PRVs) in the system (one for each zone) were not necessary for obtaining a uniform air temperature output. Manual valves upstream of each PRV were found to be sufficient for thermal balancing of the HX throughout the IRT operating ranges of airspeed and temperature.

Figure 19 illustrates the improvements obtained in air temperature uniformity with the replacement $\mathrm{HX}$. In this chart, the standard deviation of air temperature measured downstream of the $\mathrm{HX}$, at the entrance to Corner D, is plotted versus the test airspeed. Deviations are approximately $0.6 \mathrm{~F}(0.3 \mathrm{C})$ less with the new $\mathrm{HX}$ than with the old, which is a reduction of approximately 50 percent at a test airspeed of $200 \mathrm{mph}(89 \mathrm{~m} / \mathrm{s})$. Therefore, all PRVs were placed in a full-open condition pending their removal during a future 
shutdown period. This will eliminate the drop in coolant pressure at each valve and should increase the thermal effectiveness of the HX.

After both the aerodynamic and thermal subsystems of the IRT were determined by an independent review committee to be operating properly and safely, an Integrated System Test was conducted successfully that simulated a typical icing test program during a night of operation of the IRT.

Testing of the current low-temperature capability of the IRT was begun, but has now been postponed until the remotely controlled coolant valves have been removed, because this should improve the results of the tests. Figure 20 shows the preliminary low-temperature data obtained with the PRVs in place and fully open. In this chart the minimum static temperature attainable is plotted versus the test airspeed. The FAA requirement of $-22 \mathrm{~F}$ $(-30 \mathrm{C})$ is shown, together with the design requirement for the new HX (Option E) and a more ambitious design goal (Option F). These options represent upper and lower bounds on low-temperature test data measured in 1995 with the original $\mathrm{W}$-shaped $\mathrm{HX}$ in operation. The test data shown in the figure are at an airspeed of $350 \mathrm{mph}$ (156 meter/s) with all pressure regulating valves in place, with and without an icing spray.

A quantitative measure of the cooling performance of a heat exchanger is its thermal effectiveness, defined as the ratio of the drop in air temperature across the HX to the difference between the inlet air temperature and the internal coolant temperature. In Figure $\mathbf{2 1}$ some preliminary data on the thermal effectiveness of the new HX are compared with performance data for the original HX. As expected, the higher face (inlet) airspeeds into the new $\mathrm{HX}$ reduce its thermal effectiveness somewhat, compared to the W-shaped HX with its much lower face speeds for the same test airspeed. However, these preliminary data still indicate that the performance of the new HX under icing test conditions will meet design requirements and may be close to the design goal shown in Figure 20 after the 24 PRVs are removed.

Calibration of the uniformity, droplet size, and liquid water content of the icing cloud was a major element of the activation program, consuming almost 60 percent of the activation operating time. Because of the major changes made to the quality of the airflow entering the spraybar section of the tunnel, hundreds of spray nozzles were repositioned to obtain the maximum uniformity of ice accretion in the Test Section. ${ }^{8}$ Icing uniformity was assessed by measuring the thickness of ice deposited on a grid of steel bars with a spacing size of 6 in. by 6 in. (152 mm x $152 \mathrm{~mm})$. Figure 22 is a layout of this uniformity grid and the nomenclature used to record ice thickness data. Figure $\mathbf{2 3}$ is a typical contour plot of the variability of ice accretion across the Test Section, expressed as deviations of local thickness from the average thickness.

Improving the quality of the airflow entering the spraybars has had a small negative effect on the uniformity of the icing cloud. The higher turbulence and angularity produced by the original W-shaped heat exchanger actually helped to mix the water droplets into a more uniform cloud. The current upgrades have reduced the turbulence and flow angularity, and the water droplets from each spray nozzle tend to remain in a narrow stream rather than mix with droplets from adjacent nozzles. For this reason, icing uniformity appears to have degraded somewhat. ${ }^{8}$

Aero-thermal calibration of the Test Section was performed, following standard procedures used earlier in the IRT and other wind tunnels at the Glenn Research Center. Airspeeds, flow angles, turbulence, and temperatures were measured at grid points spanning the middle section of the Test Section, to produce statistical data like that shown in Figures 24 and 25. Detailed descriptions of these and similar calibration charts for the modified IRT are available. ${ }^{9,10}$

The final step in the activation program was a verification that current ice shapes agree with those produced in the past in the IRT, for a standardized airfoil model tested under standardized conditions of airspeed, temperature, time, and liquid-water content in the icing cloud. Current shapes of rime ice and glaze ice were found to match previous shapes within allowable limits.

\section{Operating Time to Date}

The IRT was operated for a total of 571.1 hours during the activation test program, without incident. As of November 17, 2000, the total operating time on the modified IRT was 978 hours.

\section{Lessons Learned}

The following are important lessons learned during this program, grouped according to their phase of the upgrade program. A recommendation is given for each.

\section{Demolition and Construction Phases}

1. The cost of abatement of lead paints was approximately 4 percent of the cost of demolition and construction. This effort was added after entering into the prime contract, and a separate funding source was obtained.

Recommendation: During the design phase, provide sufficient time and funds for environmental cleanup work. 
2. During demolition of the roof of the old C-D leg, large quantities of rainwater and condensation were found to be trapped in spaces between the tunnel ceiling and the roof insulation, within the insulation itself, and between the insulation and the roof plates. While the outside roofing material had been repaired frequently, there was no way to prevent condensation of moisture between the roof and the ceiling plates.

Recommendation: As was done in this project, apply spray-on insulation to the outsides of the floor and ceiling plates to prevent condensation, and install drains in new and old ceiling plates of the tunnel.

3. Aligning the new steel structure of the C-D leg with the old steel structure after demolition presented difficulties, because the old structure was not dimensionally correct. Placement of steel frames was started at the inlet to Corner $\mathrm{C}$, using the centerline of the Vent Tower and fan as a reference. This led to mismatching of the new and old steel at the outlet from Corner D, where distortions in the airflow are most detrimental to the flow quality in the Test Section.

Recommendation: Begin the placement of new steel at the section nearest to the entrance to the Test Section, using the centerline of the Test Section and Convergence as a reference. Work away from the Test Section. Ideally, work from both ends toward a middle position with some tolerance for misalignment, such as the expansion joints near the HX.

4. At both of the interfaces between the old ceiling structure and the new, the old ceiling was found to have sagged significantly in the middle of its 29.2$\mathrm{ft}(8.89-\mathrm{m})$ span. Jacking was required to raise the old ceiling to a level position before the new ceiling plates could be welded in place. This caused delays in the project. In addition, the new steel frames supporting the ceiling plates had to be re-analyzed for the additional downward loads imposed when the jacks were removed. Fortunately, there was adequate margin of safety in the design of the new steel.

Recommendation: Shore up long spans before demolition, and include expected fit-up loads in the structural design.

5. Finished segments of the new composite turning vanes were stored outdoors for up to two months prior to installation, so the fabricator planned to protect their flow surfaces with sheets of a staticcling plastic film. However, just before the parts were shipped, a change was made to a spray-on coating. The properties of this substitute coating actually deteriorated with exposure to the sun, causing the coating to adhere tightly to the vanes. Extensive hand labor was required to remove the film residue and repair the flow surfaces. Insufficient resistance to ultraviolet radiation appeared to be the cause of the deterioration of the coating.

Recommendation: Assure by test, if necessary, that any packaging and protective materials that are in direct contact with parts stored outdoors are UV tolerant.

6. The new $\mathrm{C}$ - and $\mathrm{D}$-Corner turning vanes required precise placement to minimize any angularity in their outflow. Although the design called for using the tunnel centerline as a flow-line reference, the Contractor elected to use the new walls instead. This led to cumulative position errors, project delays, and additional costs. When the turning vanes were relocated with the centerline as a reference and starting point, in accordance with the design, installation of the vanes was performed without significant alignment discrepancies.

Recommendation: Do not permit alternate methods of alignment of position-critical components to be used without specific review and approval of design personnel. For installations of multiple components, where walls are irregular and relative position and alignment are critical, start at the center of the installation and use only center lines as references.

7. The design of the coolant supply pipes called for only a single pressure gage at the top of each of the two main supply headers from which the two units of the HX received coolant. As a result, pressures throughout the system of headers and secondary headers were unknown during the checkout and balancing of the HX modules. Additional gages were required that had to be installed during the reactivation test phase, which caused project delays.

Recommendation: For a complex multi-path flow system, like the coolant supply piping to the HX modules, locate sufficient pressure gages for checkout and balancing, and not just the few needed for routine operation.

\section{Reactivation Testing Phase}

8. During the first operation of the IRT, readings from the new thermocouples in Corners $\mathrm{C}$ and $\mathrm{D}$ were erratic and meaningless. The problem was traced to charges of static electricity building up on the fiberglass turning vanes as air flowed over them. This had not been a problem previously because 
the old turning vanes were steel and well grounded to the tunnel floor and ceiling plates. Grounding straps were added to the vanes, which solved the problems with the thermocouples.

Recommendation: During the design phase, provide adequate grounding of instrumentation such as thermocouples and strain gages mounted on non-metallic structures. Provide additional protection from an accumulation of static potential by draining the charge at an isolated metallic sleeve or guard surrounding the sensing element.

9. Uniformity of temperature across the entire outflow of the HX was a critical design requirement. Therefore, a network of valves was provided so that the coolant flow to each of three streamwise zones within each of the eight HX modules could be controlled independently. In the final HX design, a manual flow control valve (FCV) followed in series by a remotely controlled pressure regulator valve (PRV) controlled the flow to the supply header for each of these 24 zones. In addition, the eight PRVs controlling flow to the downstream zones were provided with automatic feedback control loops, responding to downstream thermocouple signals.

During the checkout and balancing of the HX, it was determined that the uniformity of temperature across the outflow of the HX was within desired limits without the use of any of the PRVs or feedback control.

Recommendation: Remove the 24 PRVs and replace them with no-loss spool pieces, eliminating the $2.5 \mathrm{psi}(17 \mathrm{kPa})$ pressure drop through each.

10. When static pressures were measured upstream and downstream of the new HX, it was determined that the pressure drop had been underestimated by about 70 percent during the final design phase. It is clear from this large error in predicting pressure losses that the procedures used for calculating the aerodynamic drag of this type of $\mathrm{HX}$ are not acceptable. However, the minor effect of frost on pressure loss was predicted correctly.

Recommendation: Use the measured loss coefficients from these IRT tests to calibrate improved methods for predicting the aerodynamic drag losses in HXs of this general configuration.

11. As mentioned previously, each of the new turning vanes in Corners $\mathrm{C}$ and $\mathrm{D}$ was fabricated in three sections. Sections were joined together by bolted flanges, with lateral tie plates sandwiched between the flanges to carry airloads acting along the corner diagonal. This structural configuration was chosen by the manufacturer because of the significant cost savings realized by using the same molds for many sections, and concerns that a one-piece vane without supporting tie plates might deflect excessively. Near the end of the design phase, inhouse structural analysis showed that a one-piece vane was feasible, but cost and schedule constraints prevented changing from the approved three-piece design.

During flow quality testing in the stilling chamber downstream of the Corner D turning vanes, it was determined that the flow distortions of the bolted flanges and the tie plates had been underestimated. The wakes of these extraneous structures cause small local decreases in the downstream flow, and the extra pressure drops cause a small decrease in the maximum test airspeed in the tunnel. Leadingand trailing-edge fairings have now been added to the tie plates in Corner D. Improvements in flow quality are expected, but these have not yet been verified by test.

Recommendation: During the design phase, exercise more care in predicting the aerodynamic effects of alterations to an airfoil design, even when the alterations appear to be minor. Do not permit deviations from a clean aerodynamic profile unless absolutely necessary. For example, a smooth socket joint between segments of the turning vanes should have been considered before a flanged and bolted joint.

12. Concern about OGV vibrations excited by the wakes of passing fan blades led to the requirement that their minimum natural frequency must be at least $100 \mathrm{~Hz}$. To meet this relatively high frequency, which is just above the maximum blade passing frequency, it was necessary to thicken the airfoil and reduce its aerodynamic performance. As discussed previously, vibration monitoring showed that the excitation forces from the blades were quite small, and that a thinner airfoil with optimum aerodynamic performance would have been structurally acceptable.

Recommendation: A conservative structural design approach is acceptable when the size of the excitation forces (in this case the pressure variations from passing fan blades) is unknown. Resulting aerodynamic performance penalties are limited and may even be reduced, but structural penalties such as resonant vibration can be much more severe. However, vibration test data show that the blade unsteady pressure loads on the OGV's are small, so the aerodynamic performance of nearby static airfoils such as inlet and outlet guide vanes can be optimized. 
13. The predicted lowest natural frequency of the OGV's was too high by almost 100 percent, as a result of ignoring a small clearance gap in the end support when modeling the structure. Fortunately, this error was not significant because the exciting unsteady pressures on the OGV's are small.

Recommendation: When constructing a structural dynamic model for natural frequency analysis, take care to include deviations from ideal support conditions that can reasonably be expected to occur during manufacture and installation.

Recommendations for Improvements in Procurement and Contract Management

14. For research-related construction projects, strongly consider using an RFP (Request for Proposal) solicitation in order to allow for additional selection criteria in awarding contracts.

15. For purchases of "critical" material or equipment, such as the heat exchanger in this construction project, consider issuing a "sole-source justification" to assure quality and avoid substitutions by the Prime Contractor.

16. In bid documents, clearly define multiple project phases with Notices to Proceed (NTPs) and durations that are consistent with the customer's implementation plans and any scheduled facility outages. Verify that the language in any NTP letters matches the language in the contract.

17. Clarify the roles, responsibilities, and scope of authority of the Project Manager and the Construction Manager during the design phase of the project.

18. Require the Prime Contractor to take an active role in scheduling and coordinating the work of Subcontractors, to the full extent permitted when dealing with an independent contractor. Define this role in the prime contract. Consider requiring the Prime Contractor to have a project manager onsite with authority to generate schedules and cost estimates, and negotiate contract changes.

\section{Conclusions}

1. All of the objectives of the 1999 IRT upgrade program were achieved.

2. Some reduction in the performance of the IRT was measured during the activation test program. The maximum attainable airspeed was reduced by about 7 percent under dry operating conditions, because of the higher drag losses of the replacement heat exchanger and the fan outlet guide vanes. However, drag of the new heat exchanger is relatively insensitive to frost accumulation, so airspeeds under icing conditions are affected less than under dry conditions.

3. Uniformity of icing in the test section was reduced somewhat because of less mixing of the water droplets within the icing cloud as flow turbulence and angularity were reduced by the upgrades.

4. Remote control of individual cooling zones in the replacement heat exchanger is not required for temperature uniformity downstream. Remote control pressure regulating valves can be removed from the system, reducing the coolant pressure drop through the heat exchanger and increasing maximum coolant flow rates.

5. Preliminary test data indicate that the lowtemperature performance limit of the upgraded IRT will meet the design goal under dry conditions and the design requirement under icing conditions, exceeding FAA requirements. The complete range of low-temperature limits is not yet defined as a function of airspeed, blockage, and spray conditions. The planned facility performance test has been postponed until the remotely controlled valves in the heat exchanger are removed (see Conclusion 3).

6. Operation of the modified IRT for a total of 978 hours without incident (as of November 17, 2000) indicates that start-up problems have been successfully addressed and that the tunnel is ready for normal research operations.

7. Important lessons were learned during the construction, reactivation, procurement, and contract management activities that are documented for possible application to other construction projects.

\section{References}

1. Soeder, R.H.; Sheldon, D.W.; Andracchio, C.R.; Ide, R.F.; Spera, D.A.; and Lalli, N.M.: NASA Lewis Icing Research Tunnel User Manual, NASA TM107159. NASA Lewis Research Center, 1996.

2. Irvine, T.B., Kevdzija, S.L., Sheldon, D.W., and Spera, D.A.: Overview of the Icing and Flow Quality Improvements Program for the NASA-Glenn Icing Research Tunnel, the NASA Glenn Research Center Icing Research Tunnel, AIAA-2001-0229. NASA Glenn Research Center, 2001.

3. Arrington, E.A.; Pickett, M.T.; Sheldon, D.W.: Flow Quality Studies of the NASA Lewis Research Center Icing Research Tunnel Circuit, NASA TM106545. NASA Lewis Research Center, 1994. 
4. Arrington, E.A.; Gonsalez, J.C.; Kee-Bowling, B.K.: Flow Quality Studies of the NASA Lewis Research Center Icing Research Tunnel Circuit (1995 Tests), NASA TM-107479. NASA Lewis Research Center, 1998.

5. Sanz, J.M.: Aerodynamic Design of New Expanding and Contracting Turning Vanes for the NASA Lewis Icing Research Tunnel (unpublished). NASA Lewis Research Center, October 1996.

6. Schmidt, J.F.: Aerodynamic Design of New Fan Outlet Guide Vanes for the NASA Lewis Icing Research Tunnel, NYMA Corporation (unpublished). NASA Lewis Research Center, October 1996.

7. Sheldon, D.W., and Spera, D.A.: Activation Plan for the Modified GRC Icing Research Tunnel (IRT) (unpublished). August 1999.
8. Ide, R.F.: Icing Cloud Calibration of the NASA Glenn Icing Research Tunnel, AIAA-2001-0234. NASA Glenn Research Center, 2001.

9. Gonsalez, J.C., Arrington, E.A., and Curry, M. III: Flow Quality Surveys in the NASA Glenn Icing Research Tunnel (2000 Tests), AIAA-2001-0232. NASA Glenn Research Center, 2001.

10. Gonsalez, J.C., Arrington, E.A., and Curry, M. III: Aero-Thermal Calibration of the NASA Glenn Icing Research Tunnel (2000 Tests), AIAA-2001-0233. NASA Glenn Research Center, 2001.

11. Van Zante, J.F.: Correlation of Current and Historical Ice Accretion Shapes on a NACA 0012 Airfoil in the NASA Glenn Icing Research Tunnel (unpublished). NASA Glenn Research Center, July 2001.

Table 1. -Major Upgrades to the IRT.

\begin{tabular}{|c|l|}
\hline Year & \multicolumn{1}{c|}{ Upgrade } \\
\hline 1999 & $\begin{array}{l}\text { Replace motor control electronics. Replace heat exchanger. Replace C-D leg, adding } \\
\text { basement. Replace C- and D-corner turning vanes. Add fan outlet guide vanes. }\end{array}$ \\
\hline $1996-7$ & $\begin{array}{l}\text { Install new spraybar subsystem and upgrade controls, increasing number of bars from } 8 \text { to } 10 . \\
\text { Icing cloud size and uniformity increased approximately 100 percent. Time required to } \\
\text { stabilize the icing cloud decreased 90 percent. Install cold room 3D laser scanner for } \\
\text { recording ice shapes. }\end{array}$ \\
\hline $1993-4$ & $\begin{array}{l}\text { Install new insulated siding on east half of tunnel (2-in. foam core with steel face sheets). } \\
\text { Install new wood fan blades with increased pitch, increasing max test airspeed from 305 mph } \\
\text { to 420 mph. Increase number of spraybars, from 6 to 8. }\end{array}$ \\
\hline 1992 & $\begin{array}{l}\text { Install new insulated siding on West half of tunnel (2-in. foam core with steel face sheets). } \\
\text { Install 5-component external force balance. Install video cameras and test section lighting to } \\
\text { monitor ice accretion. }\end{array}$ \\
\hline 1986 & $\begin{array}{l}\text { Replace fan drive motor, increasing power to 5,000 hp. Upgrade controls to digital Varichron } \\
\text { system. Upgrade other tunnel and refrigeration controls from analog to digital. Fabricate } \\
\text { spare set of wood fan blades. }\end{array}$ \\
\hline
\end{tabular}


Table 2. - Summary of Phases of IRT 1999 Upgrade Program.

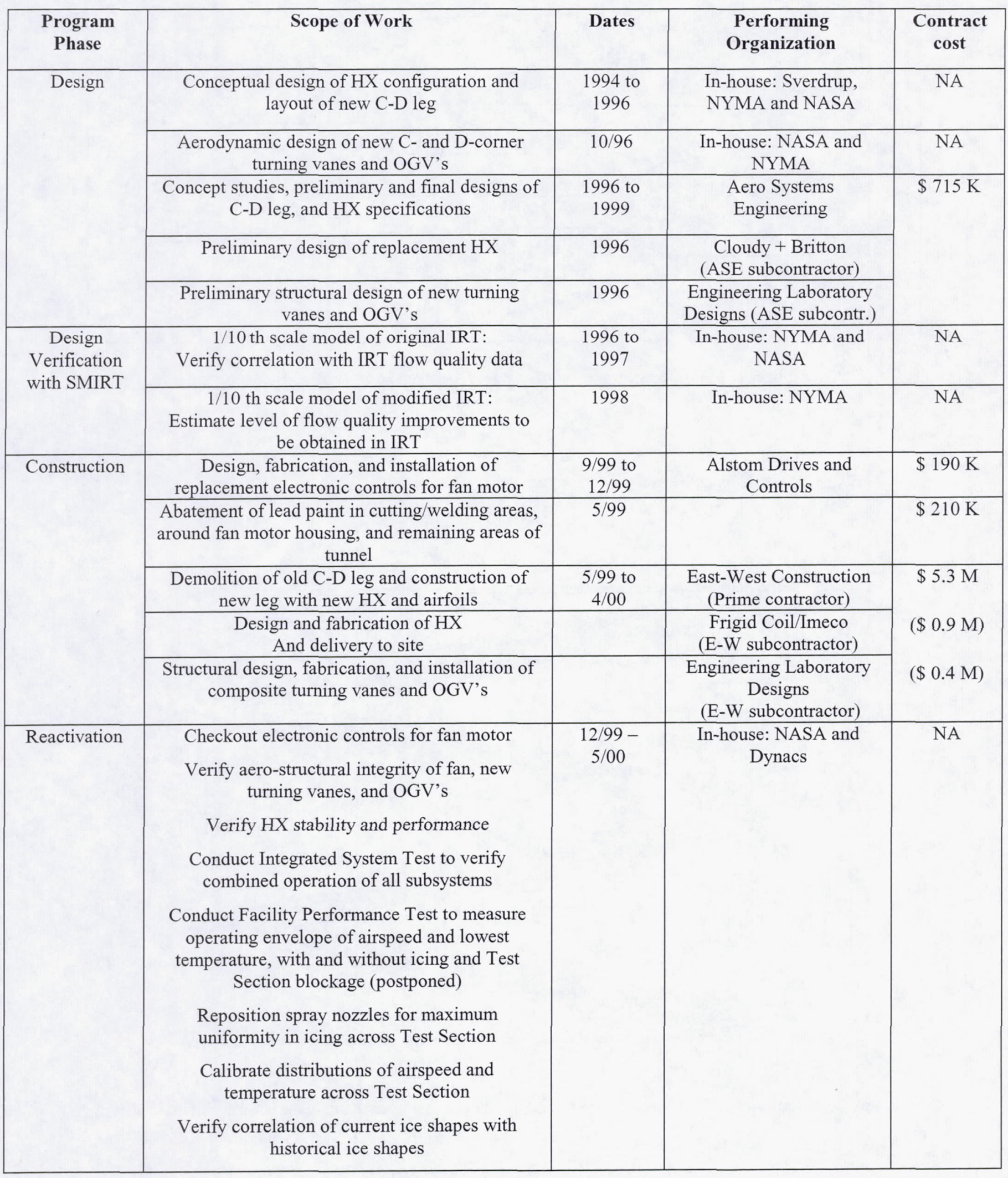




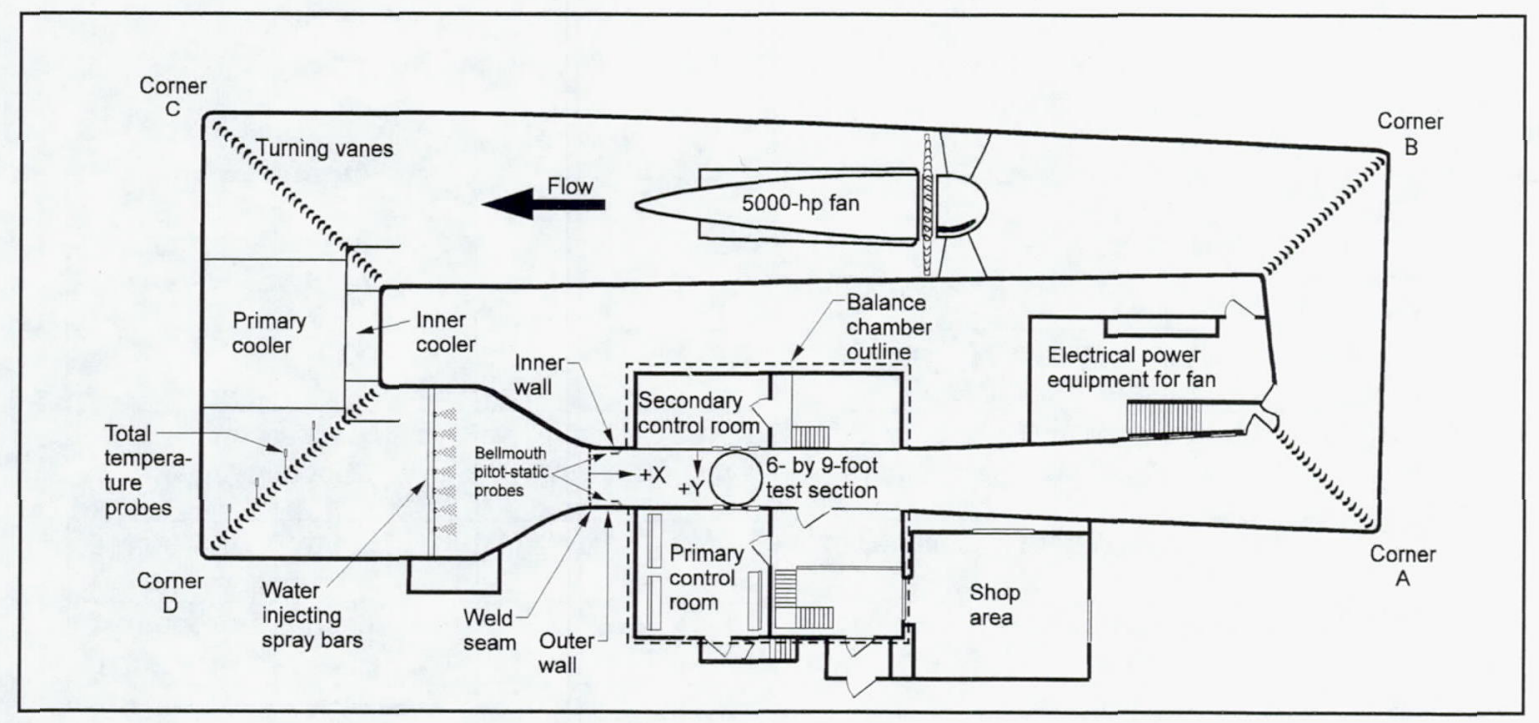

Figure 1.-Loop configuration of the IRT before the 1999 modifications.

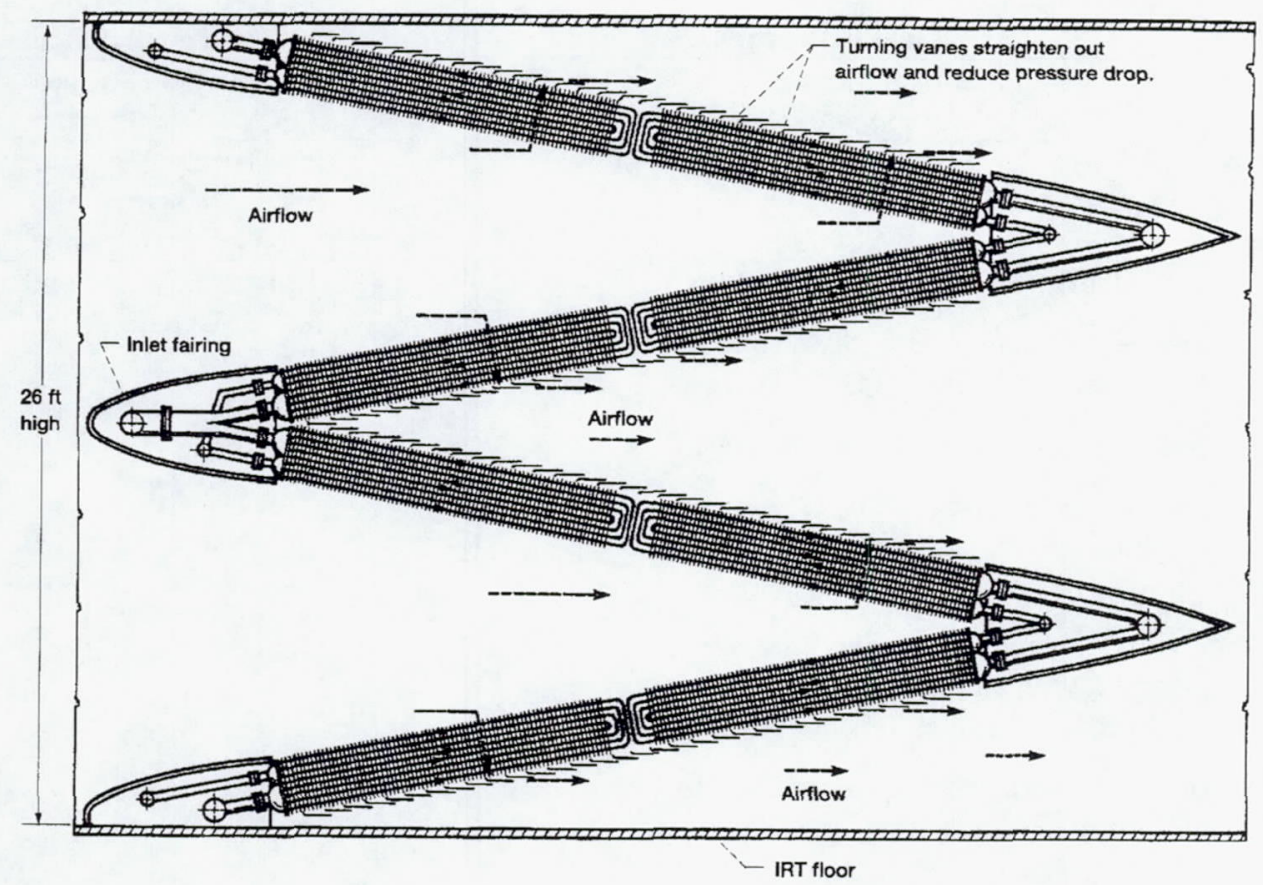

(a) Sectional view. The flow through the angled heat exchanger segments is shown schematically.

Figure 2.-Original W-shaped heat exchanger in the IRT. 


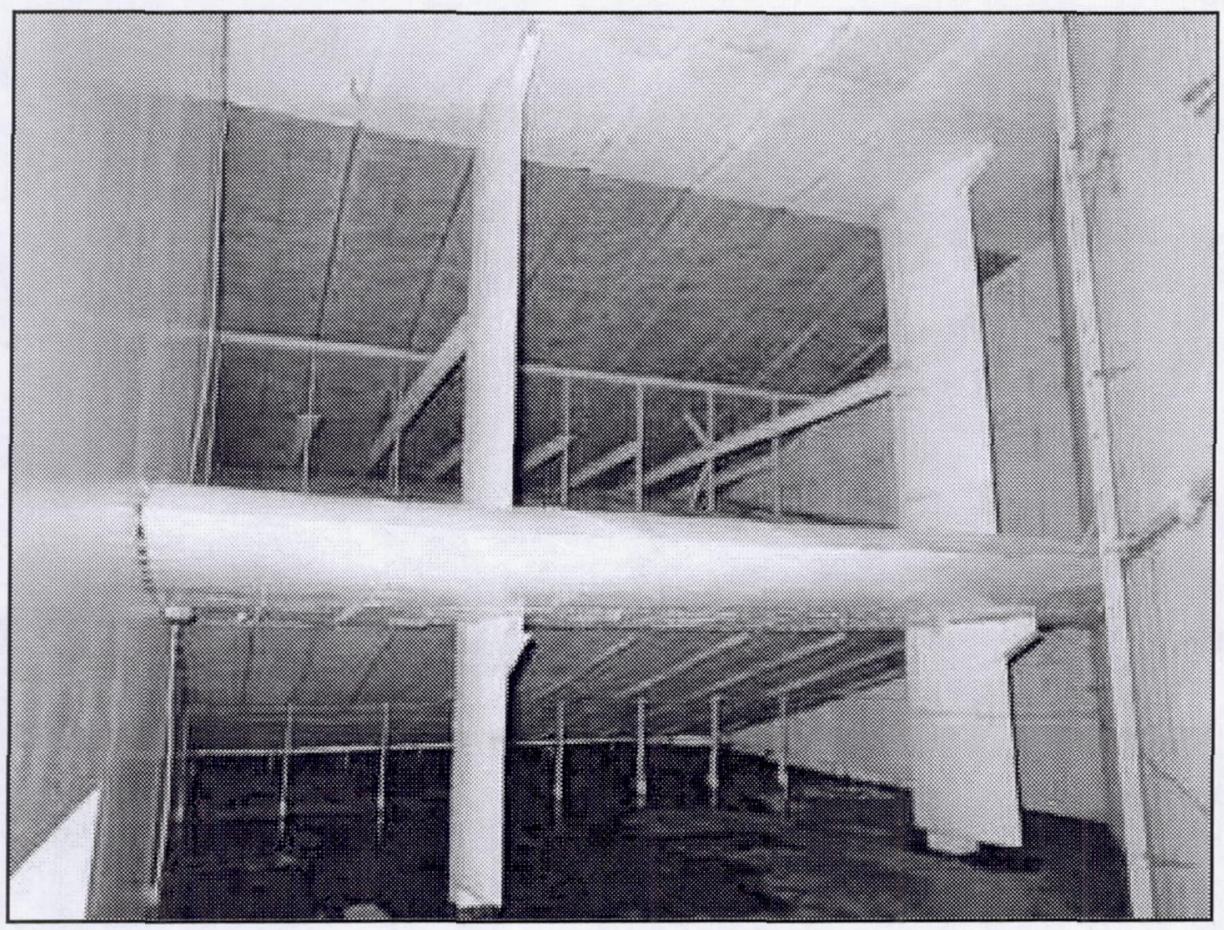

(b) View upstream of the original IRT heat exchanger. The upper layer of fin-tube panels is out of view. (C-99-1334)

Figure 2.-(Concluded) Original W-shaped heat exchanger in the IRT.

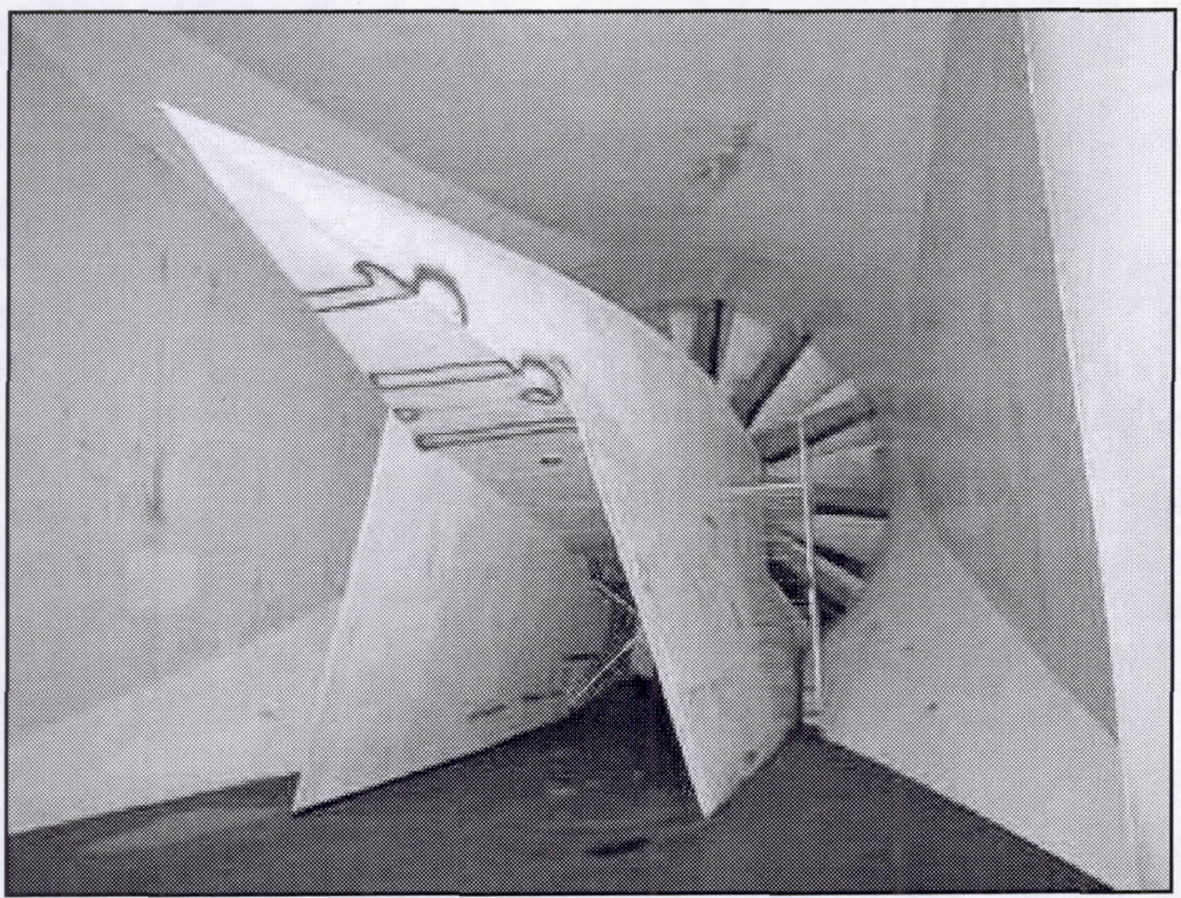

Figure 3.-View upstream of the IRT fan and motor housing. The two long fairings over the legs of the motor support platform are theorized to cause large variations in downstream air velocities. 


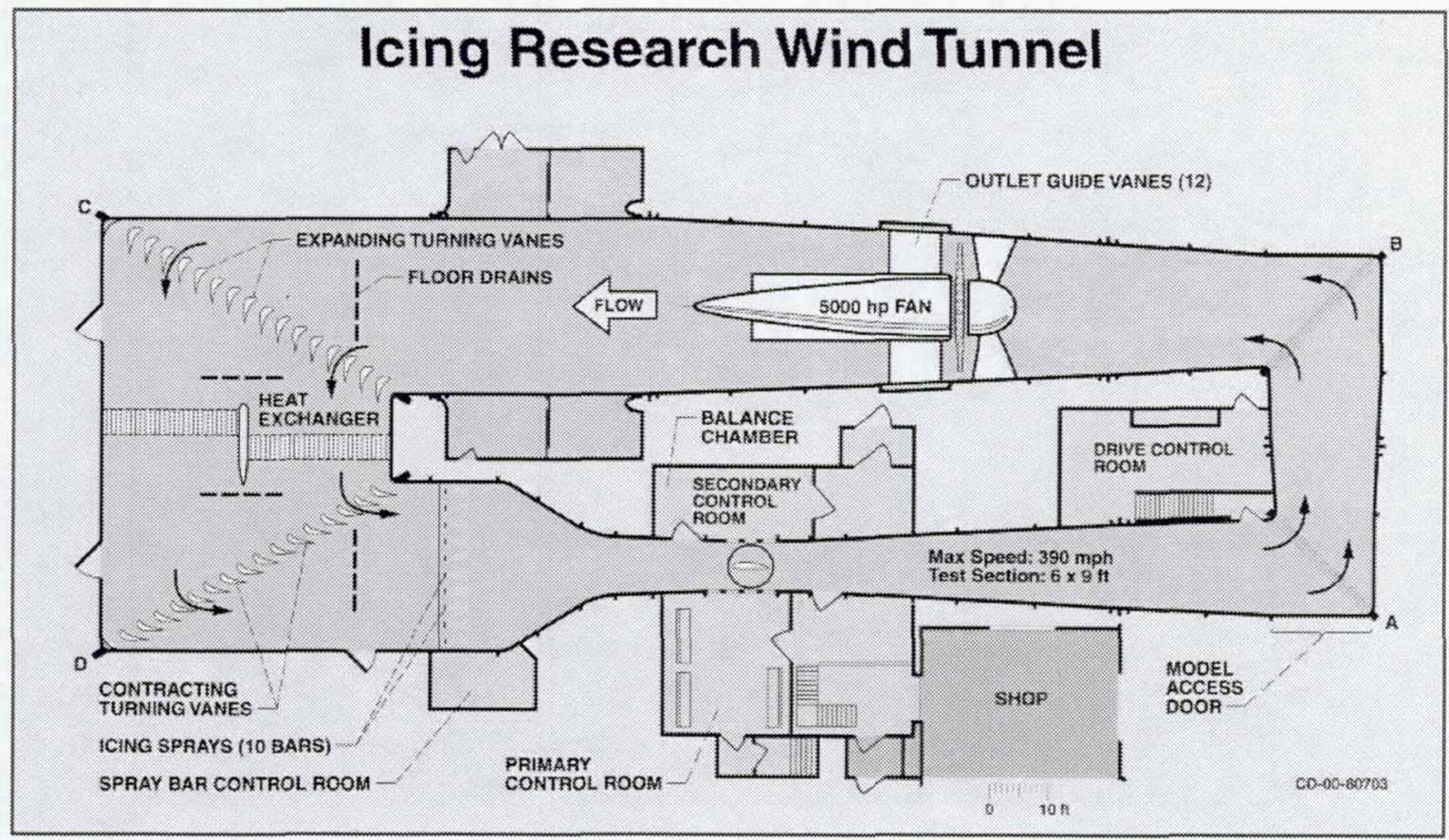

Figure 4.-Loop configuration of the IRT after the 1999 modifications. The width of the new C-D leg has been increased 69 percent to accommodate a flat heat exchanger, new turning vanes have been installed in Corners $\mathrm{C}$ and $\mathrm{D}$, and new outlet guide vanes have been installed around the fan motor housing. The electronic controls in the drive control room have also been replaced.

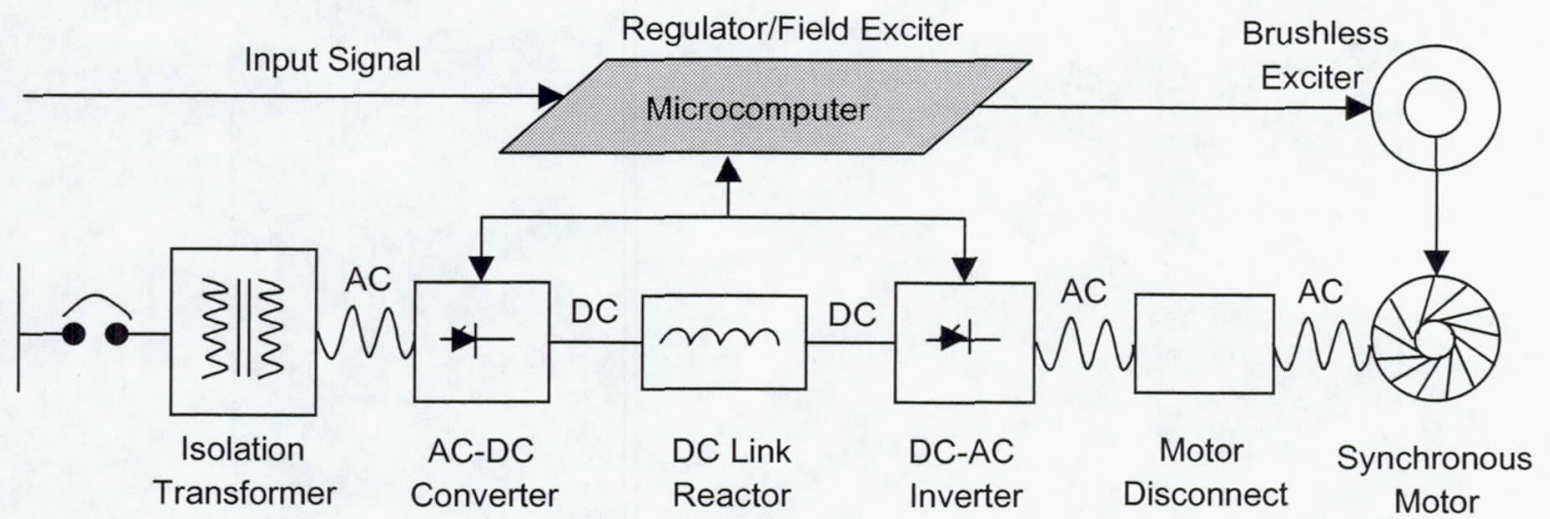

Figure 5.-Block diagram representing the various components and functions of the IRT Varichron drive system. Only the obsolete microcomputer was upgraded during this program. 


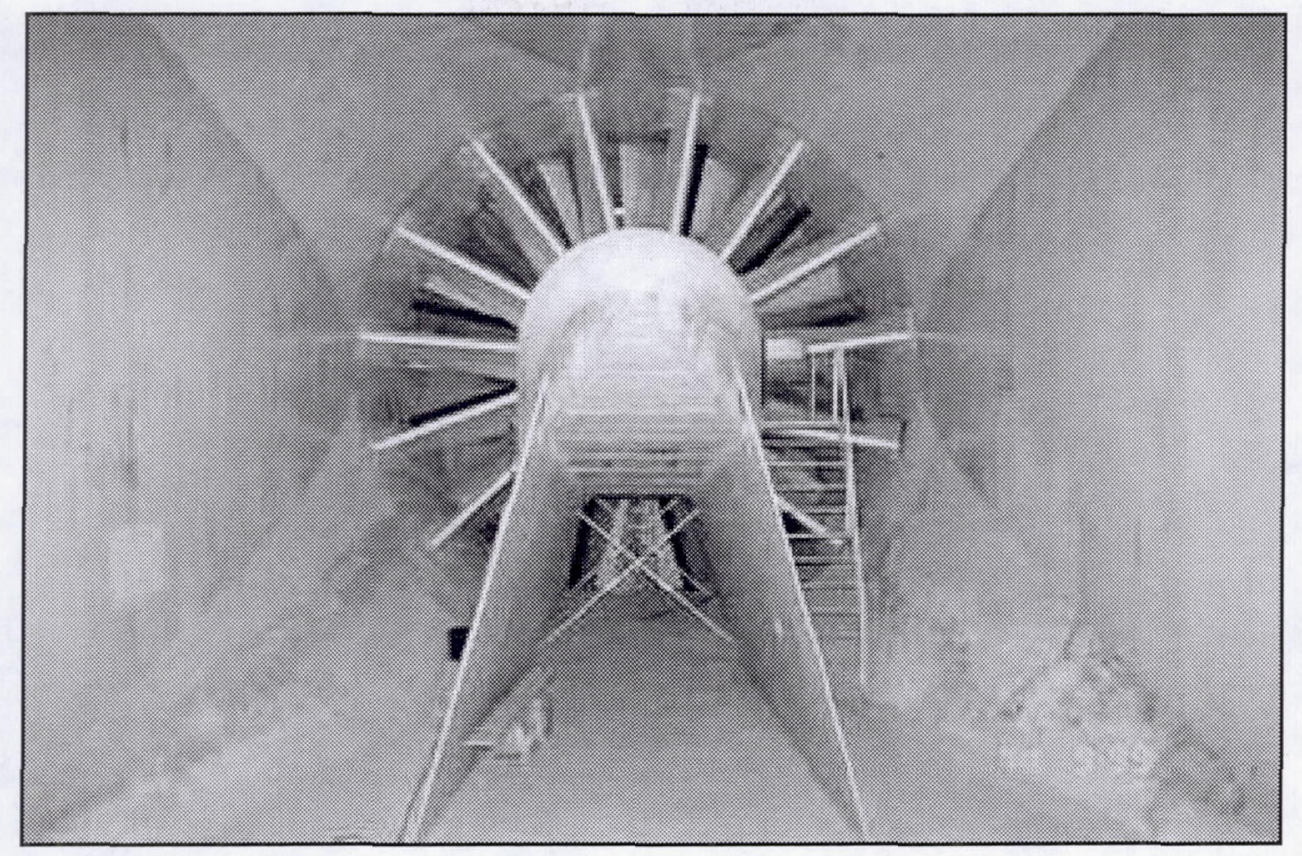

Figure 6.- Installation of the $\mathbf{1 2}$ fan OGV's around the motor housing. Views is upstream. Fan blades can be seen in the background. The leg fairings take the place of two additional OGV's. The OGV at the six o'clock position has been eliminated because it would block the primary access path to the fan blades. (C-99-2410)

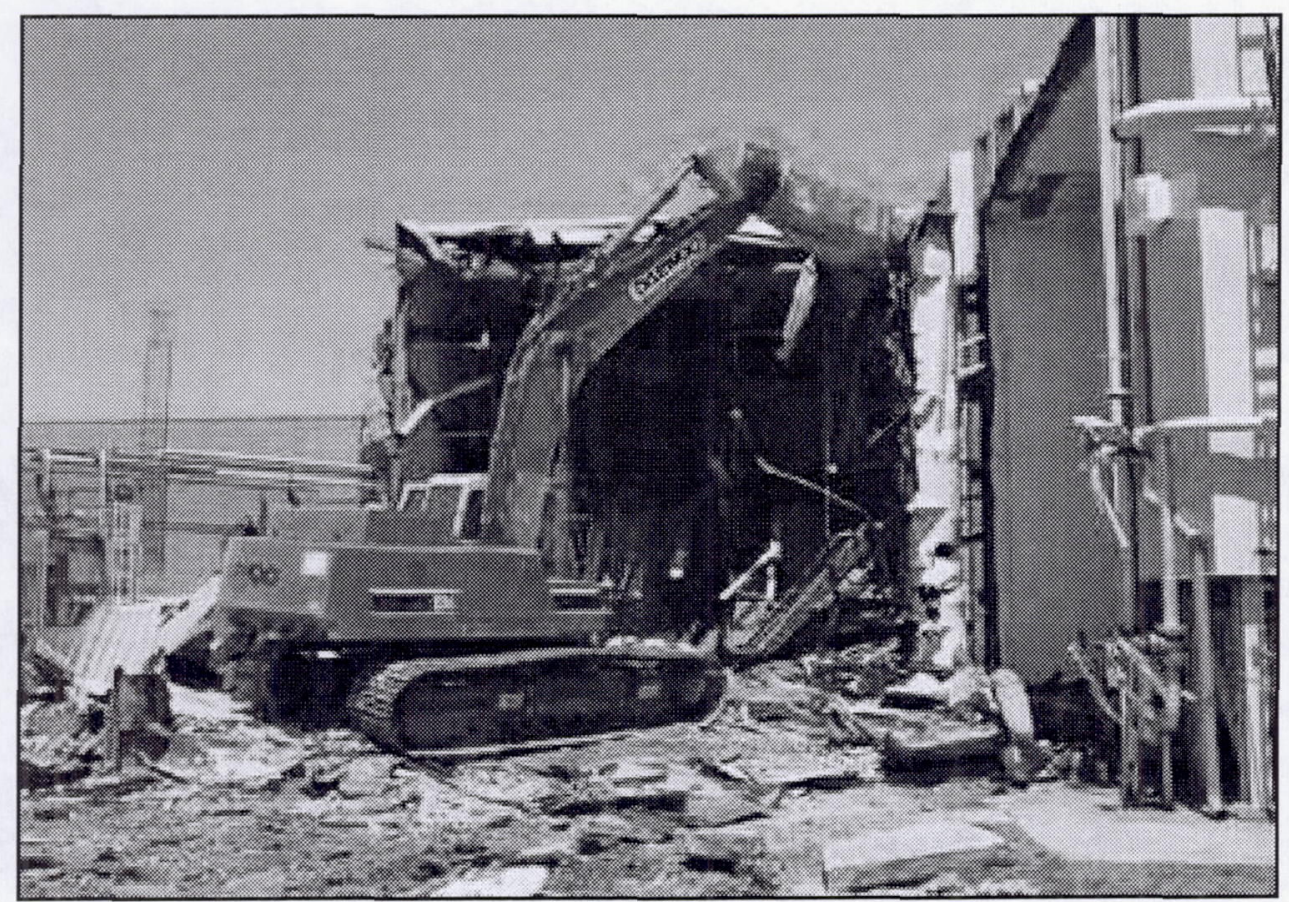

Figure 7.-Demolition of Corner D and the original heat exchanger. Corner $\mathrm{C}$ is in the background. (C-99-1452) 


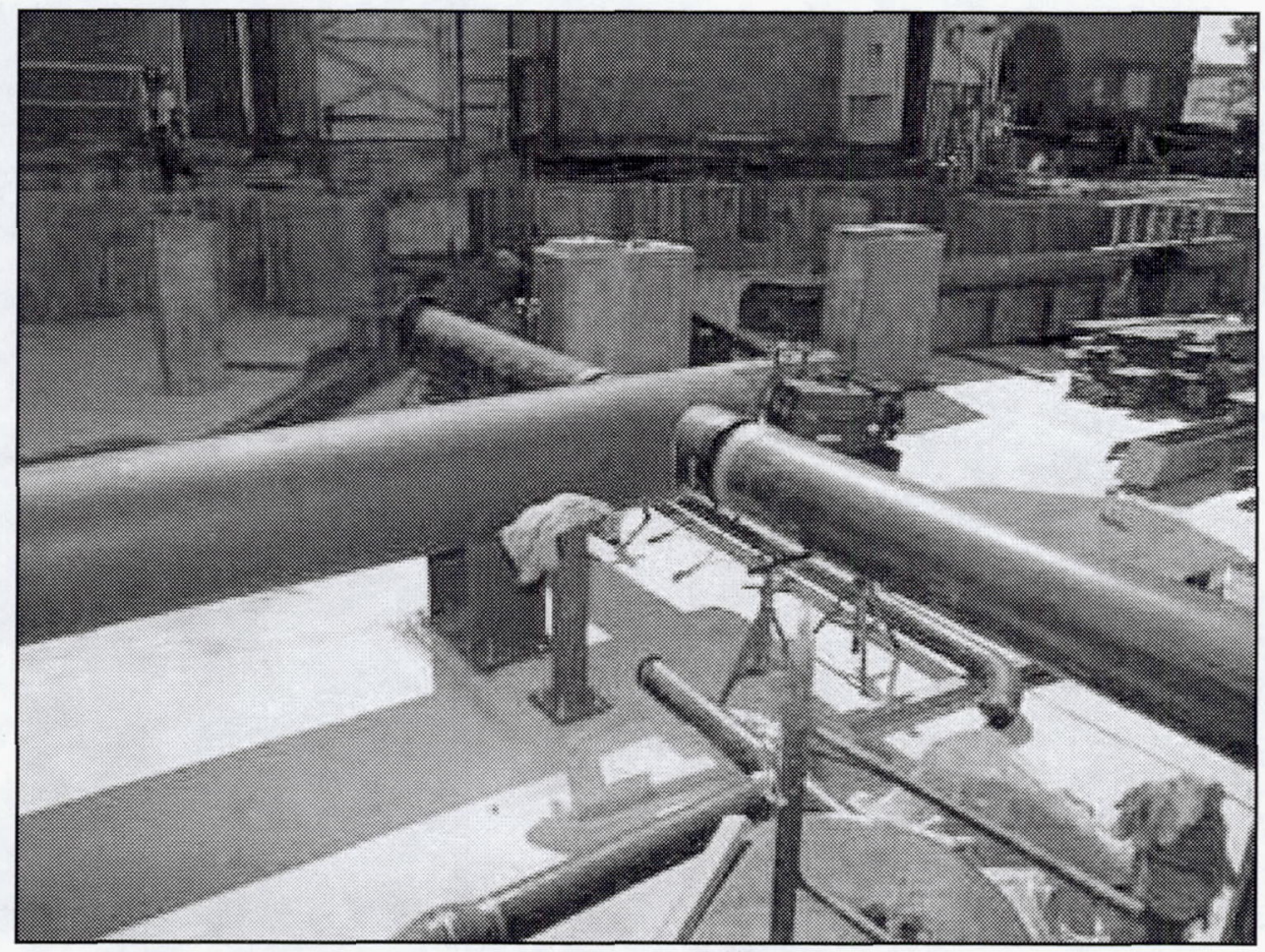

Figure 8.-Foundations for the new basement under the C-D leg. Main coolant supply and return pipes are in the foreground. (C-99-1599)

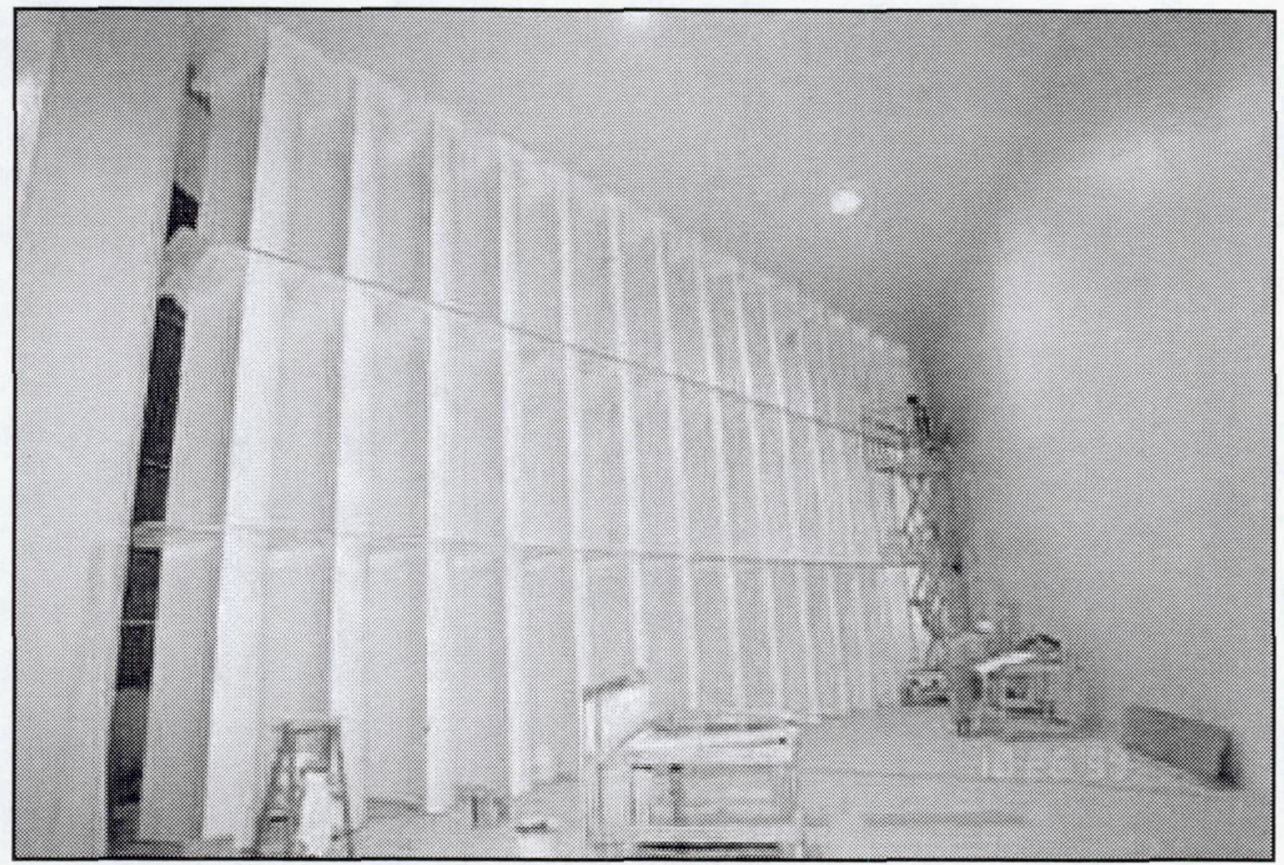

Figure 9.- Installation of the new fiberglass-composite turning vanes in Corner C. The horizontal tie plates between the vane segments help carry airloads directed outward along the corner diagonal. Socket connections at the ceiling provide for differential thermal expansion and contraction. (C-99-2287) 


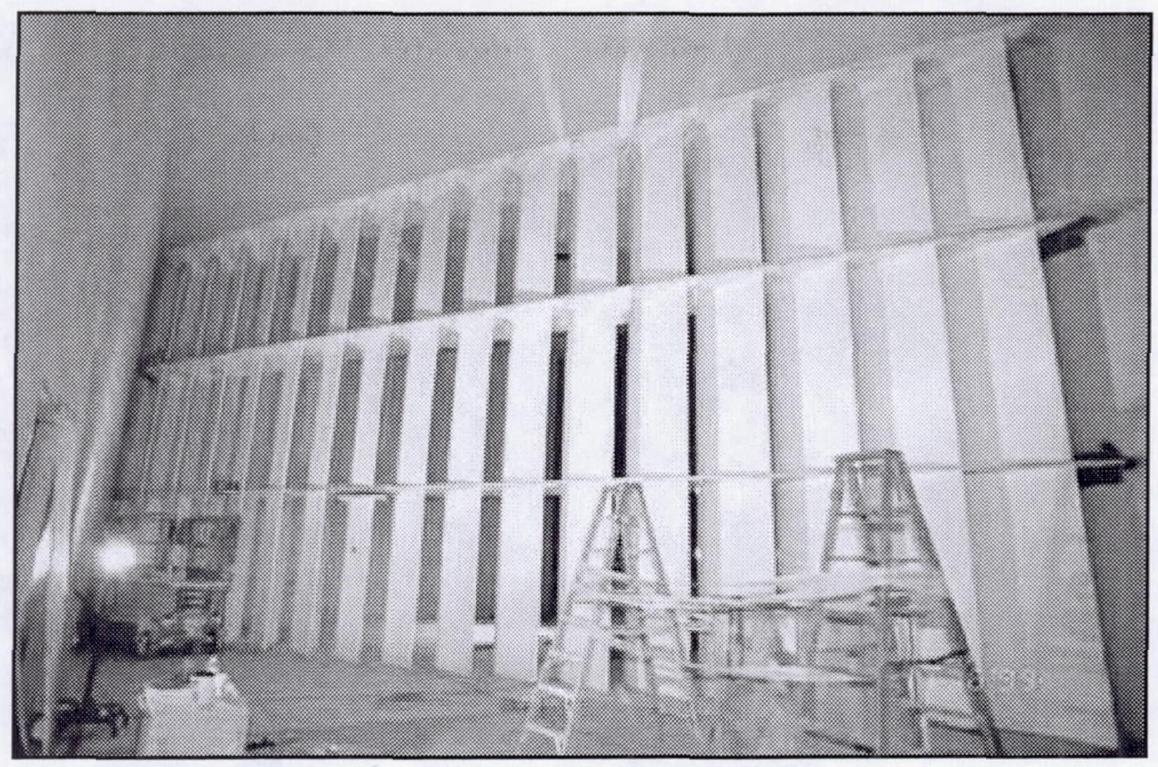

Figure 10.-View from the Stilling Chamber, looking upstream at the Corner D turning vanes. The lower segment of the seventh vane from the corner is removable, to provide access to the heat exchanger for a maintenance lift vehicle. (C-99-2285)

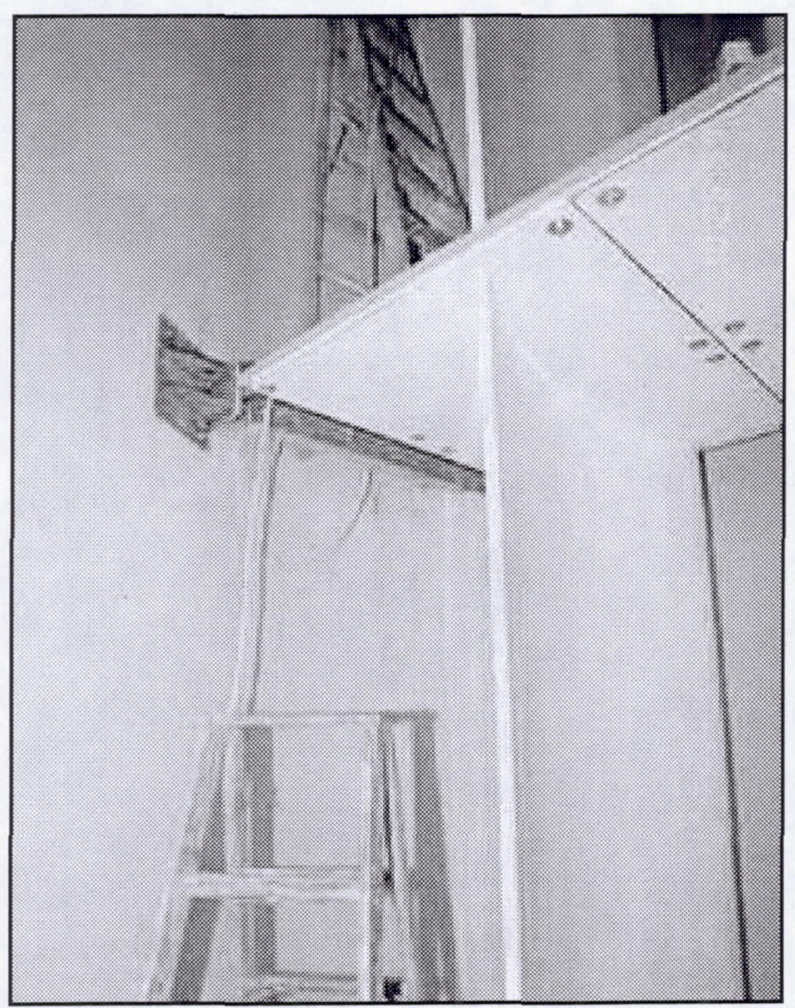

Figure 11.-View in Corner $C$ of the trailing edge of vane $C-1$, showing the outer end of a tie plate sandwiched between bolted flanges. The reinforced end of the tie plate bears against brackets on the outer wall of the tunnel. (C-99-2432) 


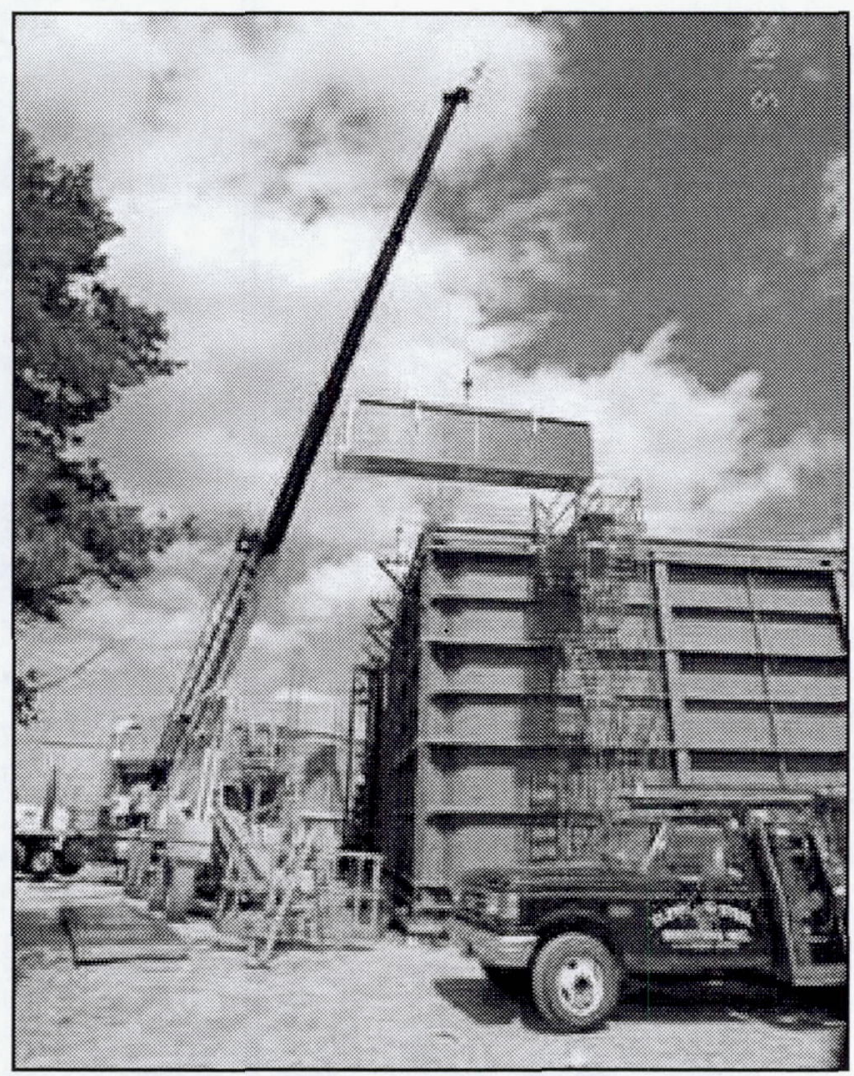

Figure 12.-Construction of the new Corner D and placing of one of the eight heat exchanger modules. (C-99-1997)

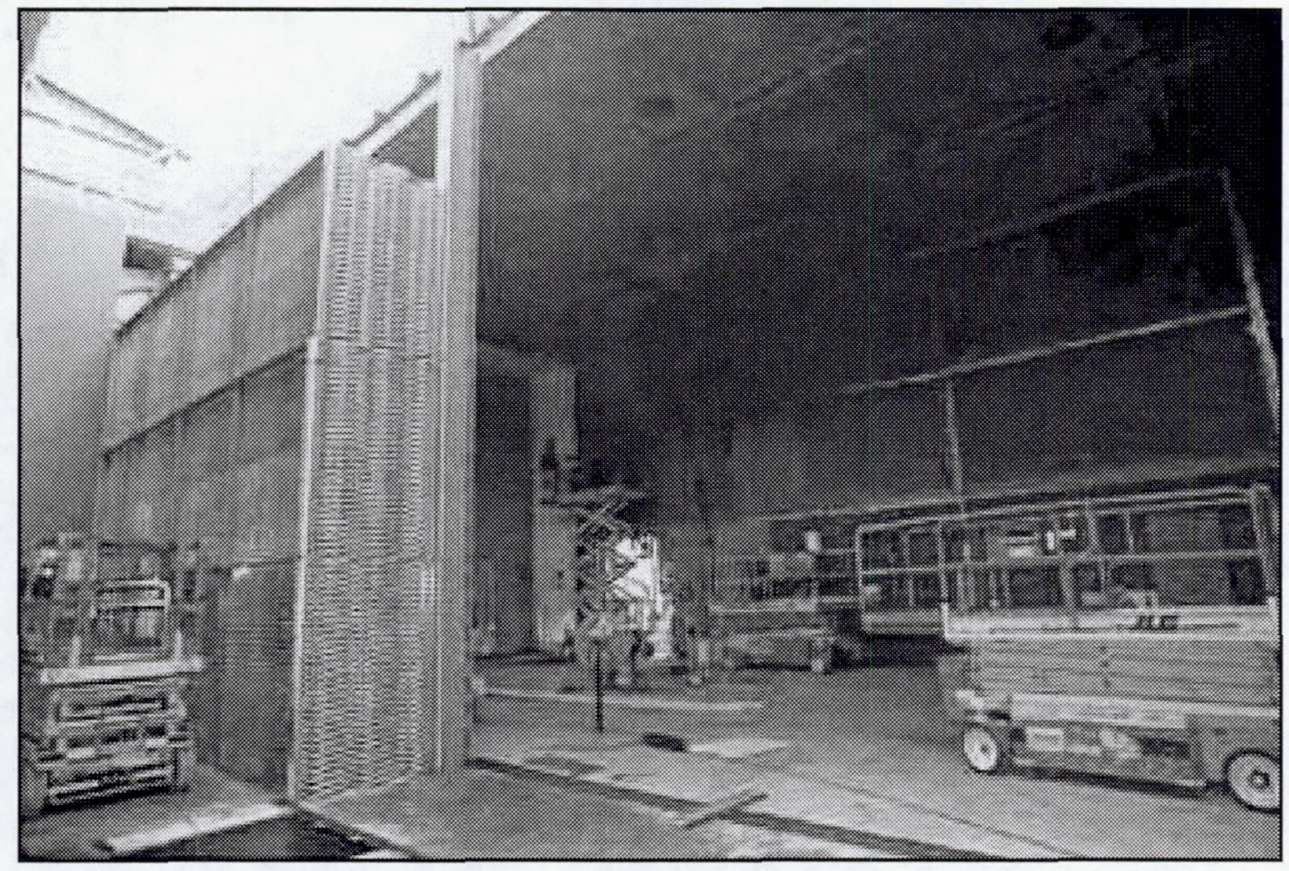

Figure 13.- Interior view of the new Corner $\mathrm{C}$ during construction, with three heat exchanger modules in place. The end turns in the aluminum coolant tubes indicate the locations of the three streamwise zones in each module. The coolant flow in each zone can be controlled independently, to minimize temperature variations in the outflow. (C-99-2005) 


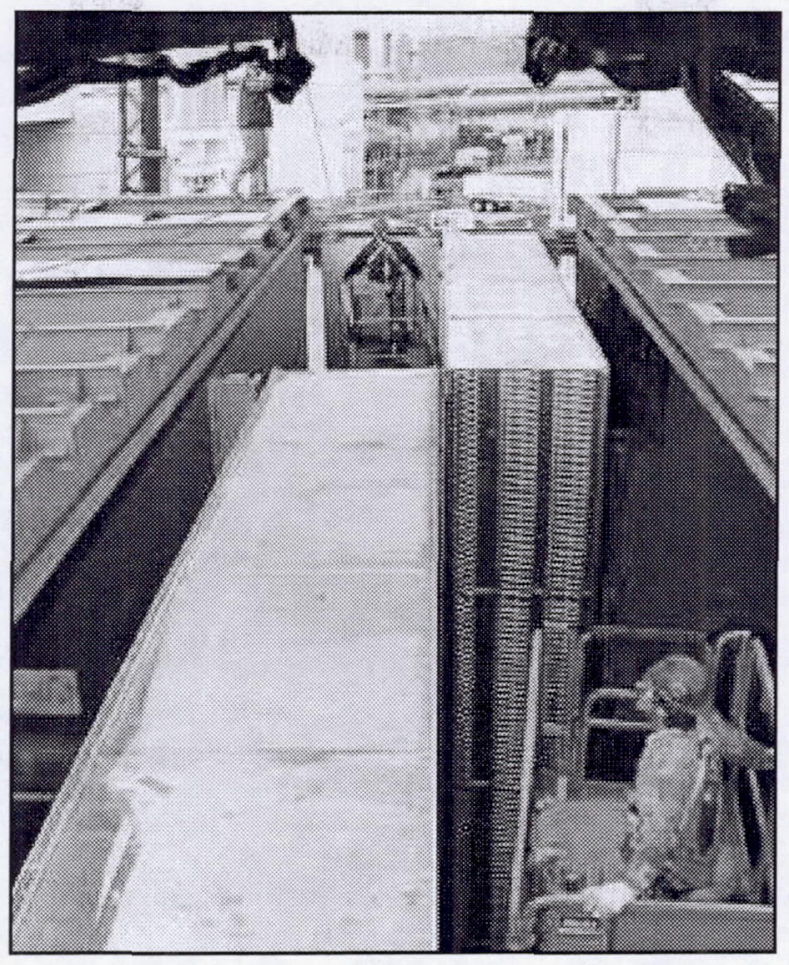

Figure 14.-View through the roof of the new C-D leg, showing the offset positions of the two heat exchanger units. The end turns in the coolant tubes are readily accessible for inspection and repair, without loss of active flow area for a corridor between units. (C-99-2178)

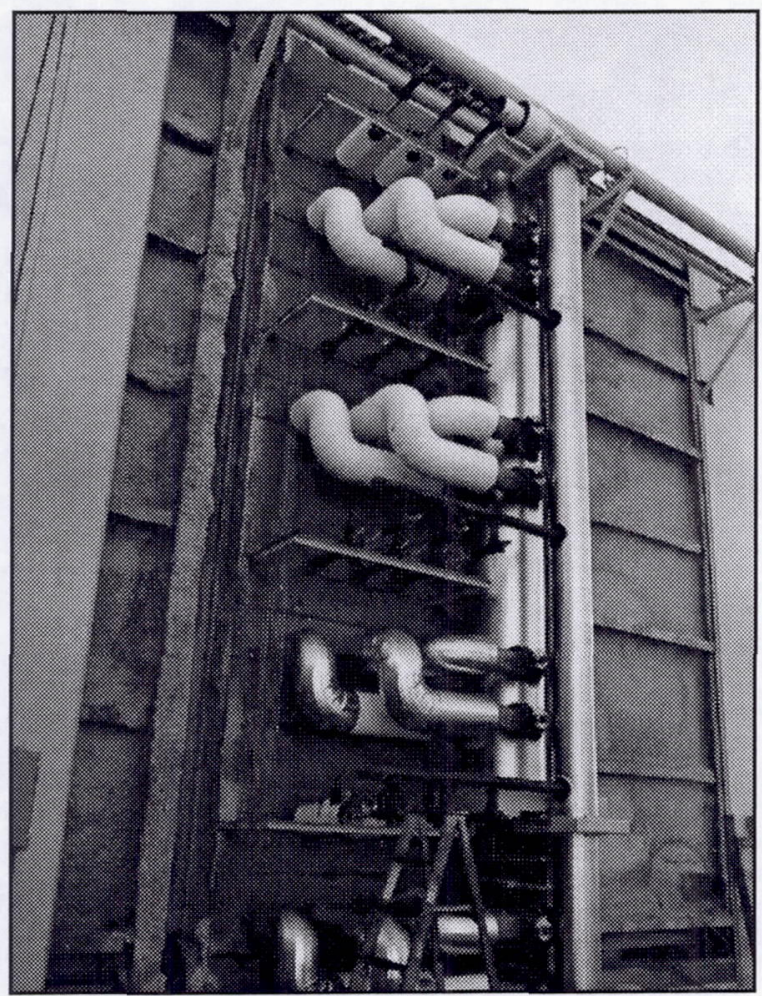

Figure 15.-View of the HX coolant supply (smaller diameter) and return (larger diameter) pipes on the West wall of the new C-D leg. Separate pairs of pipes are connected to each of the three streamwise zones in each of the four HX modules that are stacked vertically to form the West HX unit. (C-99-2655) 
Figure 16.-Typical thermocouple probe mounted on the turning vanes in Corners $C$ and $D$. Probes point directly upwind and contain two Type $T$ thermocouples. The nosepiece protects the thermocouple from ice and water, and the tubular sheath has holes that admit air at near-zero speed for accurate measurement of total temperature. (C-99-2438)

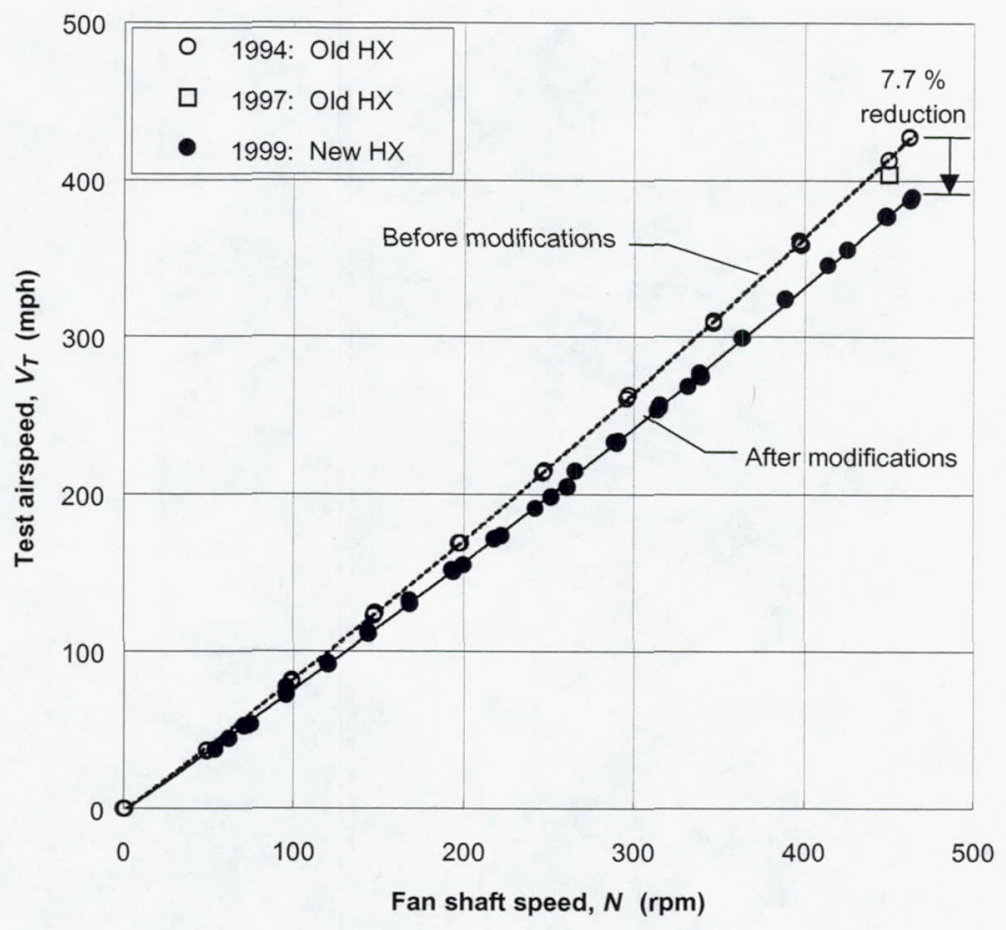

Figure 17.-Comparison of test airspeeds achievable in the IRT before and after tunnel modifications. Maximum airspeed was reduced approximately 8 percent. 


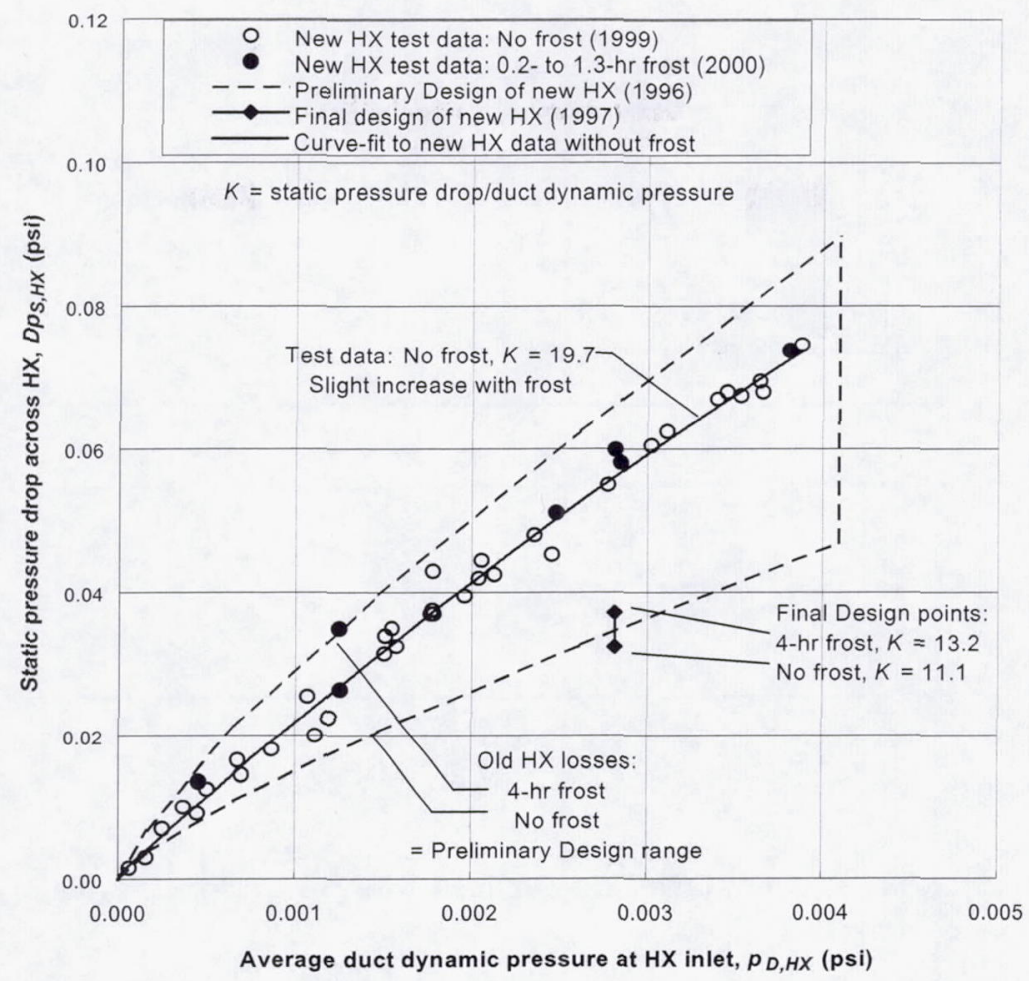

Figure 18.-Comparison of measured and design pressure drops across the replacement heat exchanger. Measured pressure drop is approximately 70 percent higher than the final design.

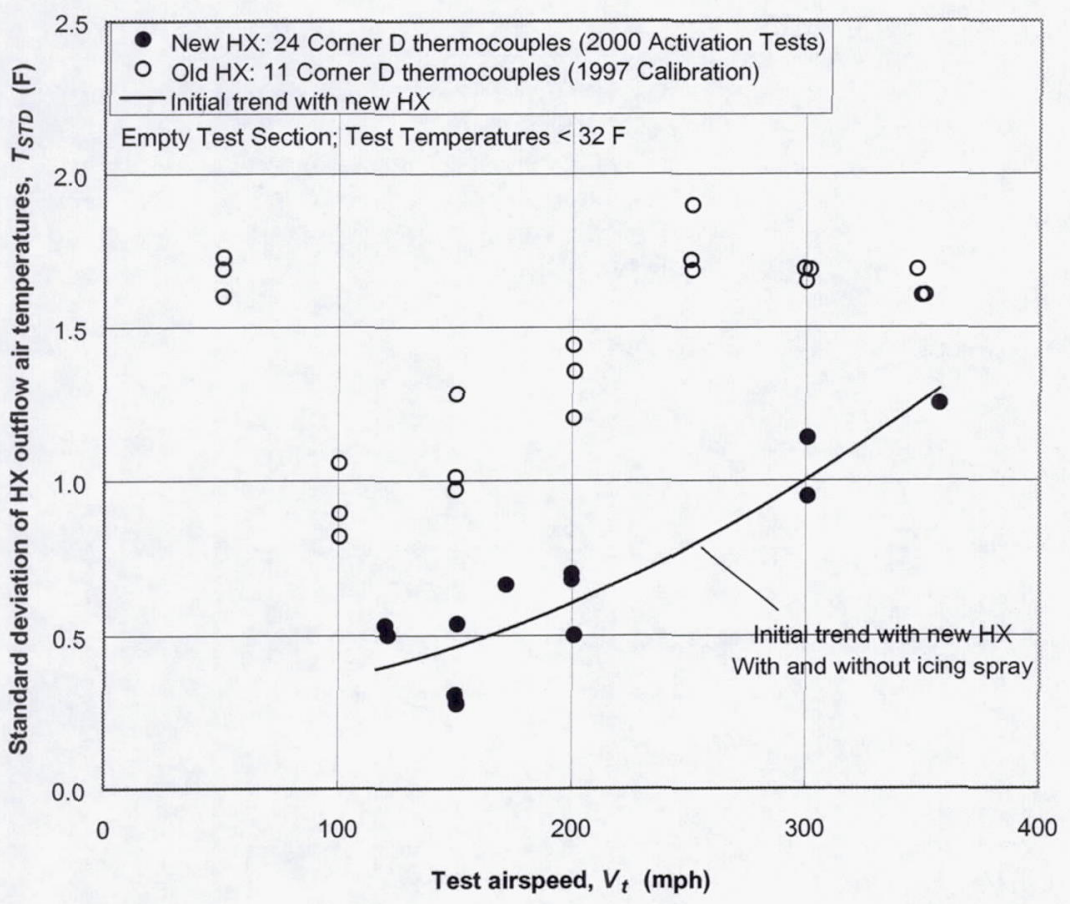

Figure 19.-Improvement in the uniformity of temperature in the outflow of the replacement heat exchanger, compared with the original heat exchanger. The standard deviation of the temperatures measured with the array of thermocouples in Corner D is used as the measure of uniformity. 


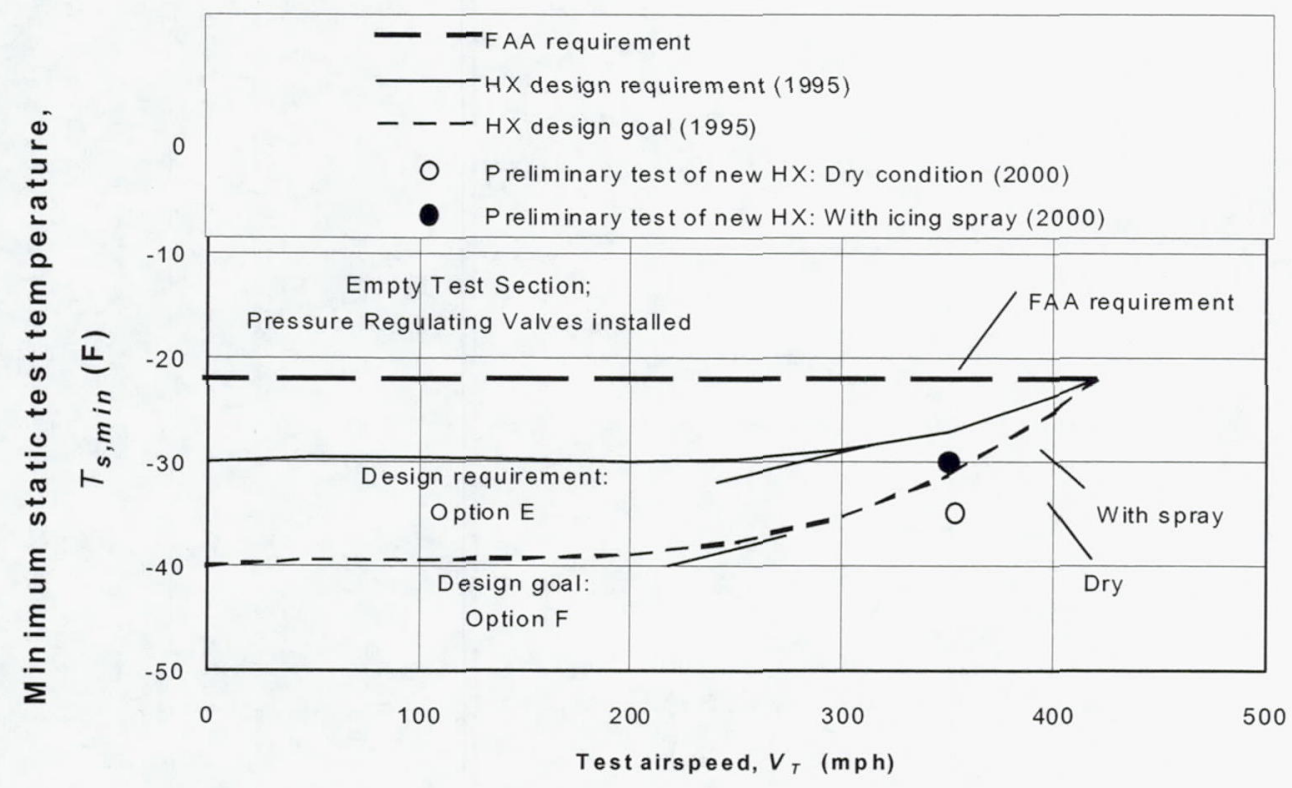

Figure 20.-Preliminary lowest-temperature data obtained with the pressure regulating valves in place and fully open.

eta $=\left(T_{C}-T_{D}\right) /\left(T_{C}-T_{F}\right)$

$T_{C}, T_{D}=$ Corner $\mathrm{C}$, Corner $\mathrm{D}$ average air temperatures

$T_{F}=$ average Freon temperature in $\mathrm{HX}$

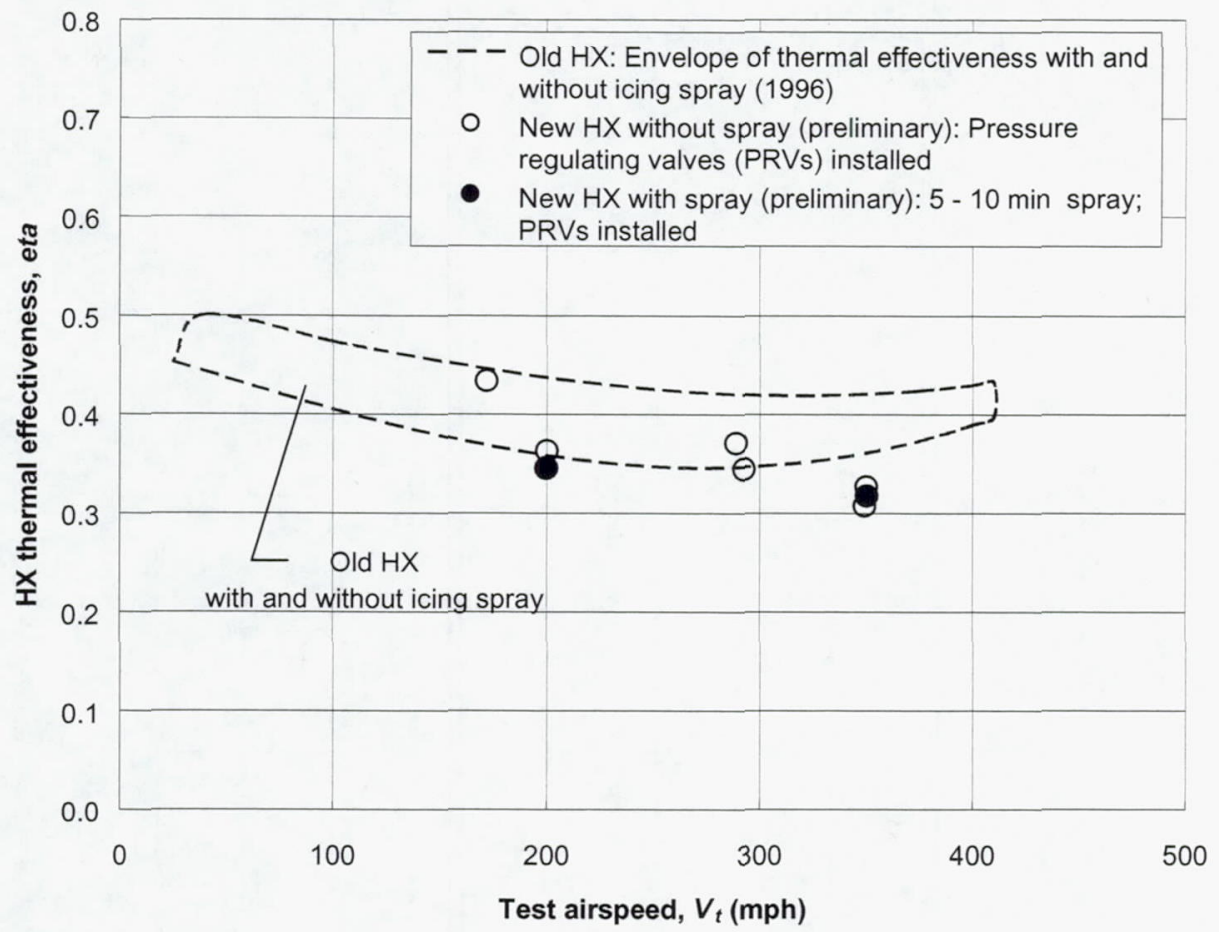

Figure 21.-Preliminary comparison of the measured thermal effectiveness of the new $\mathrm{HX}$ with that of the original HX. 


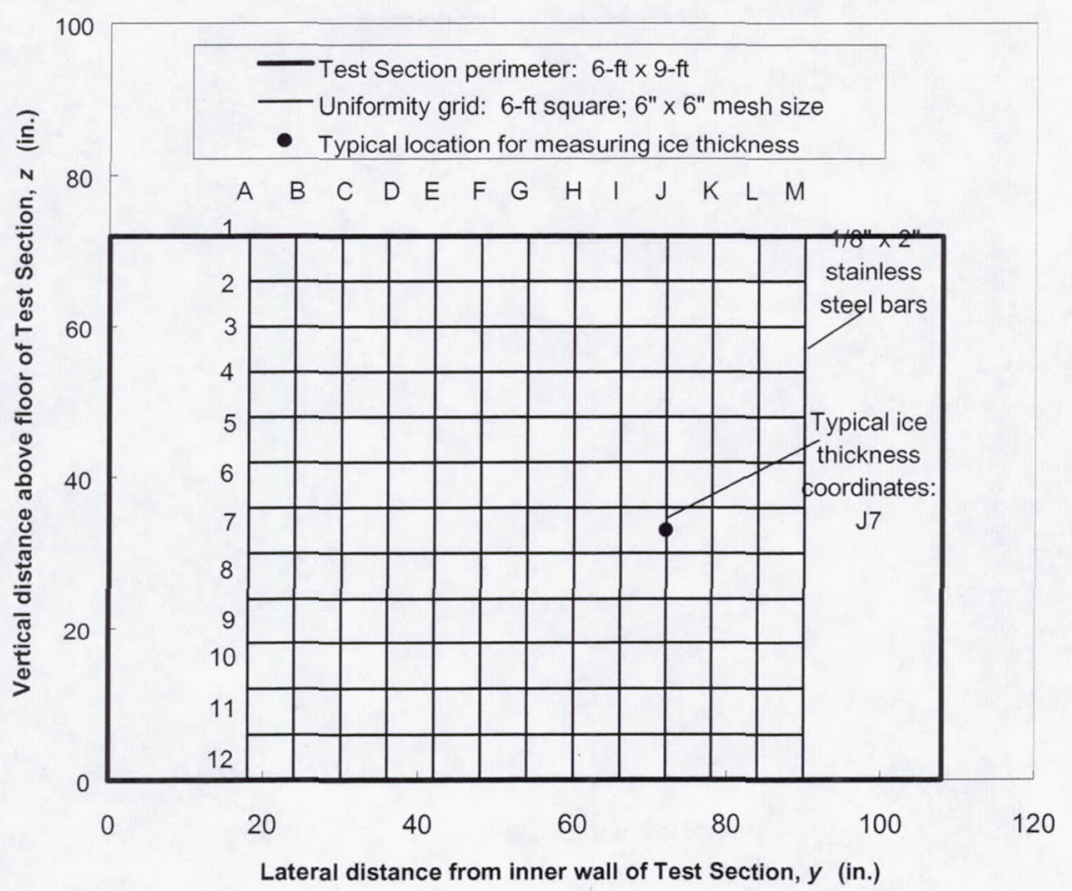

Figure 22.-Layout of the grid of steel bars used to measure the uniformity of ice accretion in the IRT Test Section.

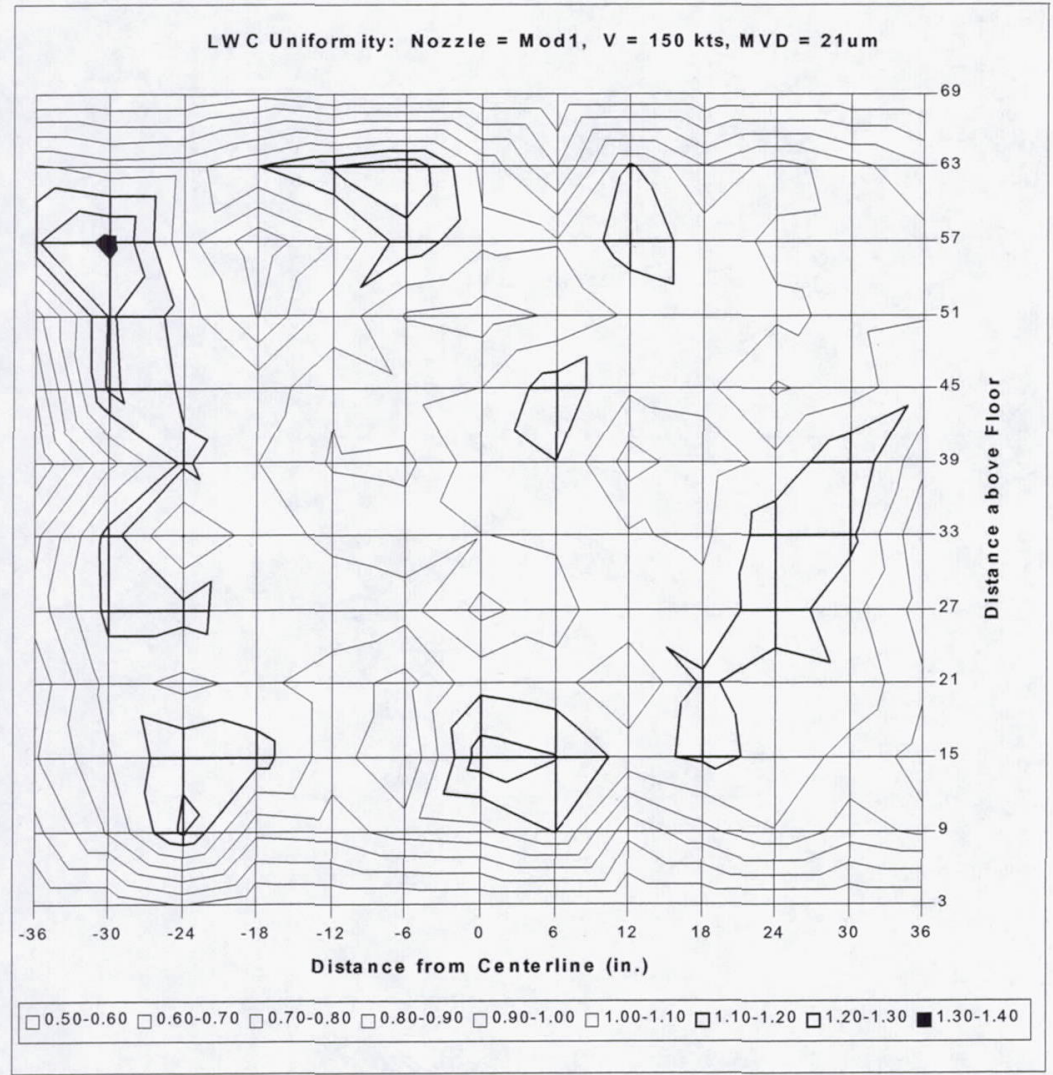

Figure 23.-Typical contour plot of the variability of ice accretion across a 6 - $\mathrm{ft}$ by 6 -ft $(1.8-\mathrm{m}$ by $1.8-\mathrm{m})$ zone in the middle of the Test Section. 


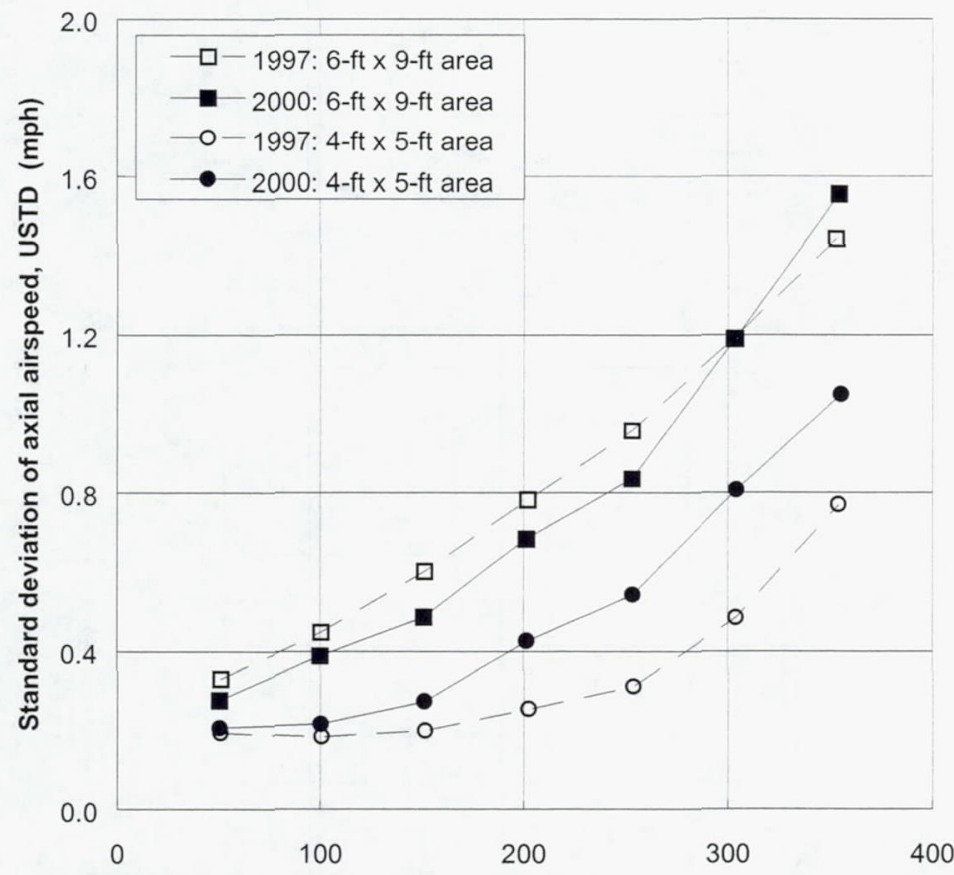

Axial airspeed in Test Section, UT (mph)

Figure 24.- Standard deviation of axial airspeed in the middle of the Test Section, as a function of the test airspeed. Airspeed deviations in the modified IRT are compared with measurements made in 1997.

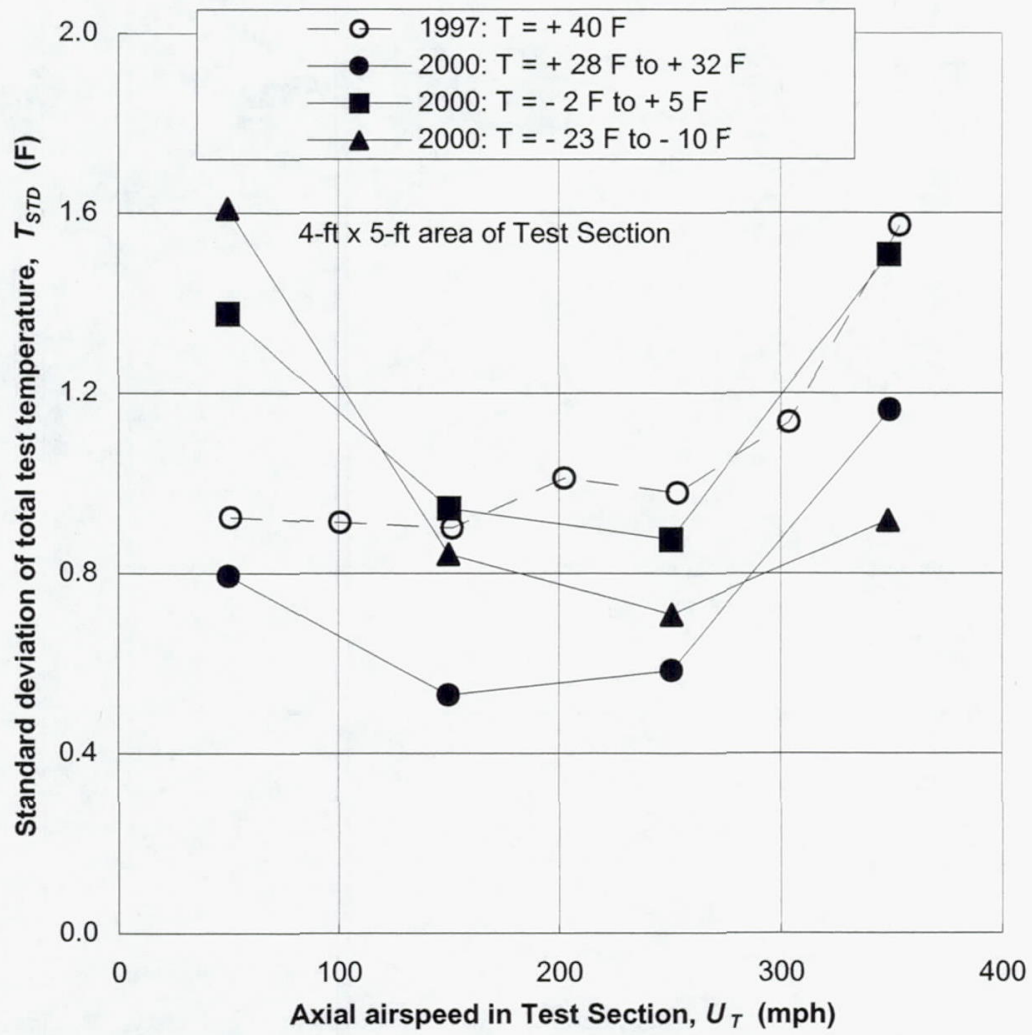

Figure 25.- Standard deviation of total test temperature in the middle of the Test Section, as a function of the test airspeed and temperature. Temperature deviations in the modified IRT are compared with measurements made in 1997. 
Public reporting burden for this collection of information is estimated to average 1 hour per response, including the time for reviewing instructions, searching existing data sources, gathering and maintaining the data needed, and completing and reviewing the collection of information. Send comments regarding this burden estimate or any other aspect of this collection of information, including suggestions for reducing this burden, to Washington Headquarters Services, Directorate for Information Operations and Reports, 1215 Jefferson Davis Highway, Suite 1204, Arlington, VA 22202-4302, and to the Office of Management and Budget, Paperwork Reduction Project (0704-0188), Washington, DC 20503.

\begin{tabular}{|l|l|l} 
1. AGENCY USE ONLY (Leave blank) & $\begin{array}{c}\text { 2. REPORT DATE } \\
\text { March } 2001\end{array}$ & $\begin{array}{r}\text { 3. REPORT TYPE AND DATES COVERED } \\
\text { Technical Memorandum }\end{array}$
\end{tabular}

\section{TITLE AND SUBTITLE}

5. FUNDING NUMBERS

Lessons Learned From the Construction of Upgrades to the

NASA Glenn Icing Research Tunnel and Re-Activation Testing

\section{AUTHOR(S)}

David W. Sheldon, Charles R. Andracchio, Thomas M. Krivanek,

David A. Spera, and Todd A. Austinson

\section{PERFORMING ORGANIZATION NAME(S) AND ADDRESS(ES)}

National Aeronautics and Space Administration

John H. Glenn Research Center at Lewis Field

Cleveland, Ohio 44135-3191

WU-708-90-1A-00

9. SPONSORING/MONITORING AGENCY NAME(S) AND ADDRESS(ES)

10. SPONSORING/MONITORING AGENCY REPORT NUMBER

National Aeronautics and Space Administration

Washington, DC 20546-0001

NASA TM-2001-210688

AIAA-2001-0231

\section{SUPPLEMENTARY NOTES}

Prepared for the 39th Aerospace Sciences Meeting and Exhibit sponsored by the American Institute of Aeronautics and Astronautics, Reno, Nevada, January 8-11, 2001. David W. Sheldon, Charles R. Andracchio, and Thomas M. Krivanek, NASA Glenn Research Center; David A. Spera and Todd A. Austinson, Dynacs Engineering Company, Inc., 2001 Aerospace Parkway, Brook Park, Ohio 44142. Responsible person, David W. Sheldon, organization code 7560, 216-433-5662.

12a. DISTRIBUTION/AVAILABILITY STATEMENT

12b. DISTRIBUTION CODE

Unclassified - Unlimited

Subject Category: 09

Distribution: Nonstandard

Available electronically at http://gltrs.gxc.nasa.gov/GLTRS

This publication is available from the NASA Center for AeroSpace Information, 301-621-0390.

13. ABSTRACT (Maximum 200 words)

Major upgrades were made in 1999 to the 6- by 9-Foot (1.8- by 2.7-m) Icing Research Tunnel (IRT) at the NASA Glenn Research Center. These included replacement of the electronic controls for the variable-speed drive motor, replacement of the heat exchanger, complete replacement and enlargement of the leg of the tunnel containing the new heat-exchanger, the addition of flow-expanding and flow-contracting turning vanes upstream and downstream of the heat exchanger, respectively, and the addition of fan outlet guide vanes (OGV's). This paper presents an overview of the construction and reactivation testing phases of the project. Important lessons learned during the technical and contract management work are documented.

14. SUBJECT TERMS

Wind tunnel; Icing; Facility upgrades; Lessons learned; Construction; Qualification

15. NUMBER OF PAGES

30 30

$\mathrm{A} 03$

\begin{tabular}{|c|c|}
\hline $\begin{array}{c}\text { 17. SECURITY CLASSIFICATION } \\
\text { OF REPORT } \\
\text { Unclassified }\end{array}$ & $\begin{array}{c}\text { 18. SECURITY CLASSIFICATION } \\
\text { OF THIS PAGE } \\
\text { Unclassified }\end{array}$ \\
\hline
\end{tabular}
19. SECURITY CLASSIFICATION OF ABSTRACT Unclassified 